\title{
Mechanisms of Connexin Regulating Peptides
}

\author{
D. Ryan King ${ }^{1}\left(\mathbb{D}\right.$, Meghan W. Sedovy ${ }^{1,2} \mathbb{D}$, Xinyan Leng ${ }^{1}$, Jianxiang Xue ${ }^{3} \mathbb{D}$, Samy Lamouille ${ }^{1,4}$, \\ Michael Koval ${ }^{5}$ (D), Brant E. Isakson ${ }^{3,6}$ and Scott R. Johnstone ${ }^{1,4,7, *(\mathbb{D})}$
}

1 Fralin Biomedical Research Institute at Virginia Tech Carilion School of Medicine, Virginia Tech, Roanoke, VA 24016, USA; ryanking@vt.edu (D.R.K.); msedovy@vt.edu (M.W.S.); xleng@vt.edu (X.L.); lamouils@vt.edu (S.L.)

2 Translational Biology, Medicine, and Health Graduate Program, Virginia Tech, Blacksburg, VA 24061, USA

3 Robert M. Berne Cardiovascular Research Center, University of Virginia School of Medicine, Charlottesville, VA 22908, USA; uxm8hs@virginia.edu (J.X.); brant@virginia.edu (B.E.I.)

4 Center for Vascular and Heart Research, Virginia Tech, Roanoke, VA 24016, USA

5 Department of Medicine, Division of Pulmonary, Allergy, Critical Care and Sleep Medicine, Emory University School of Medicine, Atlanta, GA 30322, USA; mhkoval@emory.edu

6 Department of Molecular Physiology and Biophysics, University of Virginia School of Medicine, Charlottesville, VA 22908, USA

7 Department of Biological Sciences, Virginia Tech, Blacksburg, VA 24060, USA

* Correspondence: scottrj@vt.edu

Citation: King, D.R.; Sedovy, M.W.; Leng, X.; Xue, J.; Lamouille, S.; Koval, M.; Isakson, B.E.; Johnstone, S.R.

Mechanisms of Connexin Regulating Peptides. Int. J. Mol. Sci. 2021, 22, 10186. https://doi.org/10.3390/ijms 221910186

Academic Editors: Claire Elizabeth Hills and Paul Squires

Received: 1 September 2021

Accepted: 17 September 2021

Published: 22 September 2021

Publisher's Note: MDPI stays neutral with regard to jurisdictional claims in published maps and institutional affiliations.

Copyright: (C) 2021 by the authors. Licensee MDPI, Basel, Switzerland. This article is an open access article distributed under the terms and conditions of the Creative Commons Attribution (CC BY) license (https:/ / creativecommons.org/licenses/by/ $4.0 /)$.

\begin{abstract}
Gap junctions (GJ) and connexins play integral roles in cellular physiology and have been found to be involved in multiple pathophysiological states from cancer to cardiovascular disease. Studies over the last 60 years have demonstrated the utility of altering GJ signaling pathways in experimental models, which has led to them being attractive targets for therapeutic intervention. A number of different mechanisms have been proposed to regulate GJ signaling, including channel blocking, enhancing channel open state, and disrupting protein-protein interactions. The primary mechanism for this has been through the design of numerous peptides as therapeutics, that are either currently in early development or are in various stages of clinical trials. Despite over 25 years of research into connexin targeting peptides, the overall mechanisms of action are still poorly understood. In this overview, we discuss published connexin targeting peptides, their reported mechanisms of action, and the potential for these molecules in the treatment of disease.
\end{abstract}

Keywords: connexin; gap junction; hemichannel; pannexin; peptide; cell signaling

\section{Introduction \\ Gap Junctions, Hemichannels, and Connexin Proteins as Therapeutic Targets}

Gap junction channels (GJ) were first identified in the 1960s [1-3] and have since been reported to control numerous physiologic and pathophysiologic functions. GJs are composed of connexin (Cx) proteins, of which 21 isoforms have been identified [4]. All known connexin isoforms are structurally similar, being composed of 4 transmembrane domains, 2 extracellular loops (EL1, EL2) bound in conformation by extracellular disulfide bonds, a single intracellular loop (IL), an amino-terminus (NT), and a carboxyl-terminus (CT) $[4,5]$. Variations among connexin isoforms are primarily found within the length and amino acid sequence of the IL and CT domains. Connexin proteins hexamerize to form single membrane channels called hemichannels (also known as connexons) in either the endoplasmic reticulum or the Golgi apparatus, depending on isoform, prior to trafficking to the plasma membrane [6]. Once at the membrane, hemichannels may dock with compatible hemichannels on the membrane of neighboring cells, forming GJs that permit direct intercellular cell-to-cell signaling.

GJs are non-selectively permeable to molecules up to $\sim 1 \mathrm{kDa}$ and are not considered to be highly charge selective, although charge may play a role in altering rates of transfer 
of molecules across the pore due to steric hindrance [5,7-10]. Hemichannels have been shown to function independently of GJ formation, facilitating the release of molecules such as ATP, ADP, and glutamate, and regulating $\mathrm{Ca}^{2+}$ flux in adipocytes, astrocytes, and glioblastoma cells [11-16]. While hemichannel signaling has been canonically studied at the plasma membrane, recent evidence suggests that hemichannel signaling is also present at the mitochondrial membranes [17-19]. Connexin proteins, independent of channel formation (GJ or hemichannel), have also been shown to act directly as signaling molecules, forming protein-protein interactions that regulate cellular fate [20-25]. Further, internal translation of the Cx43 protein leads to the formation of short connexin isoforms (20-30 kDa, e.g., GJA1-20k) that function within the cell to facilitate protein trafficking to the plasma membrane, mitochondrial membranes, and nuclear compartment [26-31].

GJs and connexins are dynamically regulated through protein post-translational modifications of the IL, NT, and CT [32-39]. The intracellular CT domain of most connexin proteins consists of a largely unstructured stretch of amino acids that tend to be rich in modifiable residues that can undergo nitrosylation (cysteine), phosphorylation (serine/threonine/tyrosine), and SUMOylation (lysine) as well as other modifications via acetylation, hydroxylation, and carboxylation (Figure 1) [33,40-45]. Post-translational modifications may lead to conformational changes in extracellular domains to inhibit channel docking and limit GJ formation, in pore-forming sites to alter channel permeability, and in signaling and intracellular domains that affect protein trafficking, membrane stability, and protein-protein interactions.

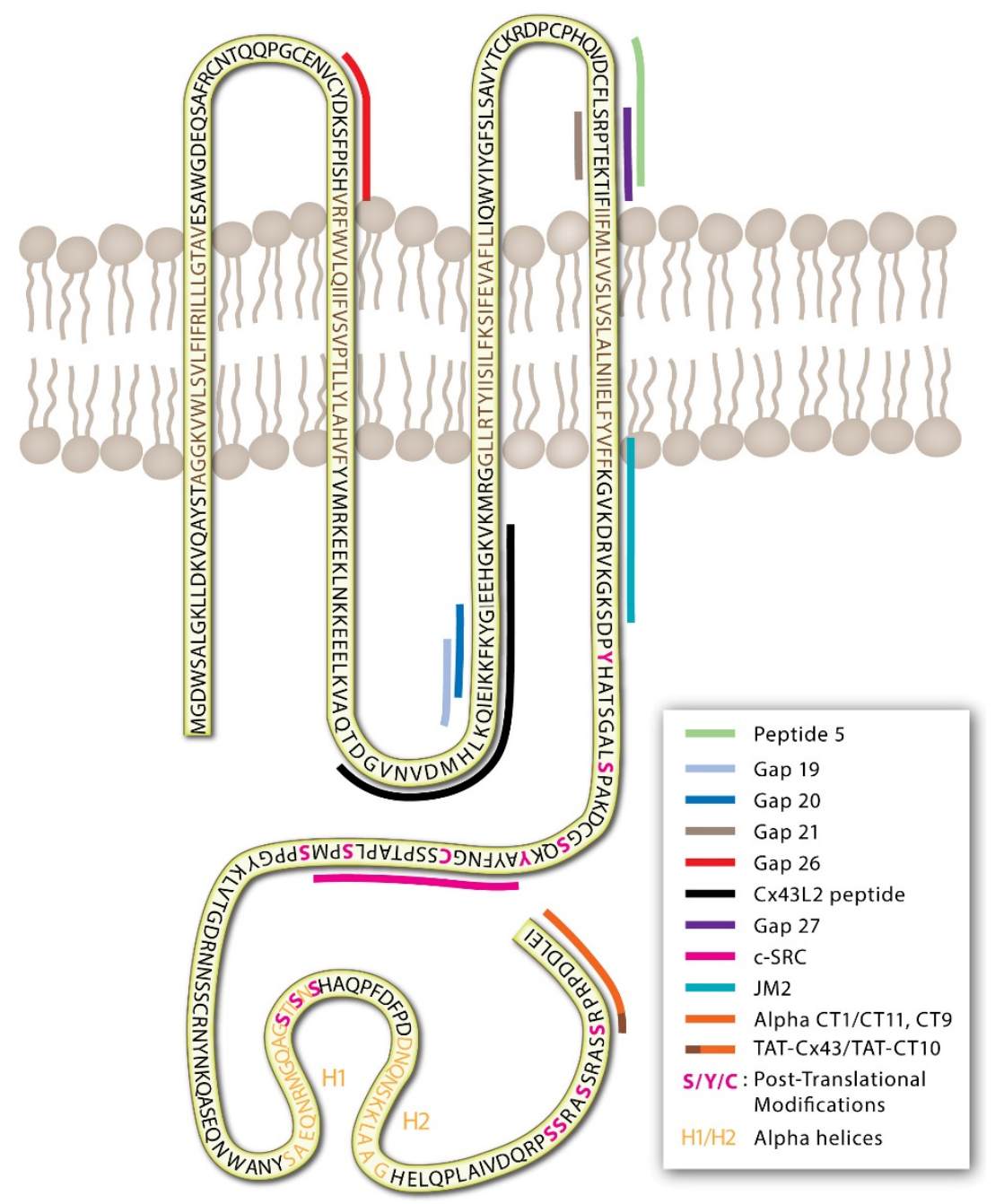

Figure 1. Schematic of the $\mathrm{C} x 43$ protein in the plasma membrane with colored lines indicating the positions of described peptides targeting EL, IL, and CT regions. 
Connexin isoform expression and function are variable throughout the body. Dysfunctional GJs are often associated with diseases such as cancer, cardiovascular disease, wound and tissue remodeling, and sensoneurial defects [5,34,46-50]. As such, GJs and connexin proteins are attractive therapeutic targets. While there are presently no therapeutics directly targeting connexin proteins or GJs that are approved for clinical use, several have been investigated in clinical trials [51-53]. The primary focus for intervention has been peptides that have indirect and direct effects on the connexin channels and protein functions. There have been many excellent reviews on connexin therapeutics and peptides developed over the last 25 years [54-59]. In this review, we focus specifically on GJ and connexin peptides that have been developed and aim to discuss the potential mechanisms through which they function. This is an area of much debate and there has been a recent push towards understanding the peptide-protein structural relationship.

\section{Indirect Acting Peptides That Alter GJs and Connexins}

$\mathrm{Cx} 43$ has long been identified as a major cardiac connexin, regulating conduction between cardiomyocytes and playing critical roles in normal heart function through GJ and hemichannel signaling [60]. Reduced Cx43 expression, altered membrane localization, and changes in connexin phosphorylation states have all been observed during ischemic heart disease and are associated with the development of cardiac arrhythmias [61-63]. In 1980, a naturally occurring anti-arrhythmic peptide, labeled AAP10, was identified in bovine serum $[58,64]$. Given the links between Cx43 dysregulation and arrhythmia development, studies of the AAP10 peptide and its derivatives (Table 1) have centered around their effects in promoting GJ function and subsequent maintenance of cardiac rhythmic conduction $[51,65]$.

As the identification of AAP10, more stable forms of anti-arrhythmic peptides have been manufactured [58]. From the original AAP10 molecule, modifications by sequence inversion and replacement by D-amino acids led to the production of ZP123 (rotagaptide), a more stable peptide analog [58]. Multiple pre-clinical trials in rat, rabbit, pig, and canine models found AAP10 and rotagaptide to preserve cardiac conduction, increase GJ signaling, and limit ischemia-induced cardiac damage and arrhythmia development [51,65-68]. Further modifications of the AAP10 led to the production of danegaptide (also referred to as ZP1609 and GAP-134), which showed a similar degree of reduction in post-ischemic infarct size in pig and canine models [69,70]. Despite the promising pre-clinical data for AAP10, rotagaptide, and danegaptide, none of these peptides were found efficacious in Phase II clinical trials $[52,58]$. The exact reason for a lack of efficacy is not clear but has been speculated elsewhere [58,71].

Despite their failure to decrease phenotypic disease burden, AAP10, rotagaptide, and danegaptide do alter the pattern of Cx43 expression, phosphorylation, GJ signaling, and hemichannel signaling $[20,72-74]$. Studies have demonstrated that these peptides increase both Cx43 and Cx40 GJ signaling [72,75]. Unlike the peptides to be discussed later in this review, the AAP10 derivative peptides do not contain sequence homology with connexin proteins. AAP10, rotagaptide, and danegaptide are not presumed to be membrane permeable. Rather, the peptides are suspected to bind with a membrane-bound G-protein coupled receptor (GPCR), although the precise receptor remains unknown [76,77]. It is hypothesized that peptide binding with a GPCR leads to the activation of protein kinase $\mathrm{C}$ (PKC) pathways, which in turn modify Cx43 and Cx40 functions [72,76]. Prolonged treatment with AAP10 and rotagaptide has been shown to increase $\mathrm{Cx} 43$ protein synthesis, expression, and membrane retention in cultured HeLa cells, primary rat ventricular cardiomyocytes, and dermal fibroblasts $[20,72,78,79]$. 
Phosphorylation is a key event in the lifecycle of most connexin proteins. For instance, in Cx43, de-phosphorylation of Cx43-S282 or phosphorylation at Cx43-S373 is linked to a reduction in GJ signaling following ischemia $[61,80]$. Conversely, phosphorylation at sites such as PKC-associated Cx43-S262 and Cx43-S368 are reportedly protective against ischemia-reperfusion injury [80,81]. In ischemic hearts, temporal reductions in site-specific Cx43 phosphorylation are associated with asystole, which is alleviated through treatment with AAP10 in rabbits and by rotagaptide in rats $[65,68]$. Both AAP10 and rotagaptide promote PKC activation, inducing Cx43-S368 phosphorylation and subsequent opening of Cx43 GJs [65,72,78,82-84]. Mass spectrometry analysis of cardiomyocytes also demonstrates that phosphorylation at S297 and S368 is lost subsequent to ischemia in untreated hearts, yet preserved by treatment with rotagaptide [58,68,85].

Studies in cultured endothelial cells suggest that danegaptide preserves Cx43 GJ signaling and reduces apoptosis under high glucose conditions [86]. In astrocytes, danegaptide treatments increase GJ and hemichannel signaling and produce protective effects such as reduced infarct volume following a stroke in mice [87]. In aged mice, danegaptide induces similar effects to AAP10 and rotagaptide, increasing Cx43-S368 phosphorylation, preserving Cx43 expression with the overall effect of reducing cardiac fibrosis [74]. In addition to membrane-associated GJ functions, these peptides were proposed to stabilize Cx43, which could limit the generation of damaging reactive oxygen species associated with mitochondrial $\mathrm{Cx} 43$. However, in murine cardiac cell preparations, danegaptide was found to exert its effects independent of mitochondrial Cx43, suggesting it may have other molecular targets and pathways outside of Cx43 [19,69,88].

The AAP10 peptide has also been proposed to enhance cancer therapeutic treatments [89], stem cell differentiation [90], and may increase homocysteine-induced cardiomyocyte cell apoptosis [91]. However, the exact pathways through which this occurs remain to be fully investigated, and more insight is required into how the anti-arrhythmic peptides function by binding GPCRs resulting in therapeutic protection.

Table 1. Connexin regulating peptides.

\begin{tabular}{|c|c|c|c|c|c|c|c|c|}
\hline \multirow{2}{*}{ Year } & \multirow{2}{*}{ Peptide } & \multirow{2}{*}{ Sequence/Formula } & \multicolumn{2}{|c|}{ Known Target Cx } & \multirow{2}{*}{ Linker } & \multirow{2}{*}{ Properties } & \multirow{2}{*}{$\begin{array}{c}\text { Increase } \\
\text { Cx43-PKC }\end{array}$} & \multirow{2}{*}{ Refs. } \\
\hline & & & $\mathrm{Cx}$ & Region & & & & \\
\hline \multicolumn{9}{|c|}{ Non-Mimetic Peptides-Indirect Effects } \\
\hline 1980 & AAP10 & $\begin{array}{l}\text { H-GAG-4hyp-PY- } \\
\text { CONH }\end{array}$ & $\begin{array}{l}\mathrm{Cx} 43^{*} \\
\mathrm{Cx} 40^{*}\end{array}$ & \multirow{3}{*}{$\begin{array}{l}\text { Indirect: } \\
\text { Unknown } \\
\text { GPCR } \\
\text { pathway }\end{array}$} & - & \multirow{3}{*}{$\begin{array}{l}\text { Increases Cx } \\
\text { synthesis, expression, } \\
\text { phosphorylation, } \\
\text { membrane targeting, } \\
\text { and GJ opening }\end{array}$} & Y & {$[58,72,76,77,84]$} \\
\hline 2003 & $\begin{array}{l}\text { Rotagaptide } \\
\text { (ZP123) }\end{array}$ & $\begin{array}{l}\text { H2N-GDAGD-4hyp- } \\
\text { DPDY-Ac }\end{array}$ & $\mathrm{C} \times 43 *$ & & NT Acetyl & & Y & [51] \\
\hline 2013 & $\begin{array}{c}\text { Danegaptide } \\
\text { (ZP1609, } \\
\text { GAP134) }\end{array}$ & $\mathrm{C}_{14} \mathrm{H}_{17} \mathrm{~N}_{3} \mathrm{O}_{4}$ & $\mathrm{C} \times 43 *$ & & - & & $\mathrm{Y}$ & {$[69,74]$} \\
\hline \multicolumn{9}{|c|}{ Extracellular Loop 1 (EL1) } \\
\hline 1997 & Gap26 & VCYDKSFPISHVR & $\begin{array}{l}\text { Cx43, } \\
\text { Cx32, } \\
\text { Cx26 } \\
\end{array}$ & $64-76$ & - & HC block & Y & {$[92,93]$} \\
\hline 2001 & ${ }^{43}$ Gap26 & VCYDKSFPISHVR & $\mathrm{Cx} 43$ & $64-76$ & - & HC block & $\mathrm{Y}$ & {$[94,95]$} \\
\hline 2009 & ${ }^{43}$ Gap26M & VCYDKSFPISHVR & $\mathrm{Cx} 43$ & $64-76$ & NT Acetyl & HC block & $\mathrm{Y}$ & {$[95,96]$} \\
\hline 2001 & ${ }^{37,40}$ Gap26 & VCYDQAFPISHIR & $\begin{array}{l}\text { Cx37, } \\
\text { Cx40 }\end{array}$ & $64-76$ & - & HC block & ND & {$[94]$} \\
\hline 1999 & Unlabelled & ICNTLQPGCNSV & Cx32 & $52-63$ & - & GJ block & ND & [97] \\
\hline 2007 & Peptide 1848 & CNTQQPCCENVCY & $\mathrm{Cx} 43$ & $54-66$ & - & GJ Block & ND & [98] \\
\hline
\end{tabular}


Table 1. Cont.

\begin{tabular}{|c|c|c|c|c|c|c|c|c|}
\hline \multirow{2}{*}{ Year } & \multirow{2}{*}{ Peptide } & \multirow{2}{*}{ Sequence/Formula } & \multicolumn{2}{|c|}{ Known Target $\mathrm{Cx}$} & \multirow{2}{*}{ Linker } & \multirow{2}{*}{ Properties } & \multirow{2}{*}{$\begin{array}{l}\text { Increase } \\
\text { Cx43-PKC }\end{array}$} & \multirow{2}{*}{ Refs. } \\
\hline & & & $\mathrm{Cx}$ & Region & & & & \\
\hline \multicolumn{9}{|c|}{ Extracellular Loop 2 (EL2) } \\
\hline 1999 & Unlabelled & SLSAVYTCKRDPCPHE & Cx43 & 180-195 & - & GJ block & ND & [99] \\
\hline 1999 & Unlabelled & FLDTLHVCRRSPCPHP & $\mathrm{C} \times 40$ & 177-192 & - & GJ block & ND & [99] \\
\hline 2001 & ${ }^{37,43}$ Gap27 & SRPTEKTIFII & $\begin{array}{l}\text { Cx43, } \\
\text { Cx37, } \\
\text { Cx32, } \\
\text { Cx26 }\end{array}$ & 201-211 & - & HC block & Y & {$[92-95,100]$} \\
\hline 2001 & ${ }^{40}$ Gap27 & SRPTEKNVFIV & $\mathrm{C} \times 40$ & $201-211$ & - & GJ block & ND & {$[93,94,100]$} \\
\hline 2011 & ${ }^{32} \mathrm{Gap} 27$ & SRPTEKTVFT & Cx32 & $182-191$ & - & HC block & ND & [101] \\
\hline 2021 & ${ }^{62}$ Gap27 & SRPTEKTIFML & CX62 & $201-211$ & - & HC \& GJ block & ND & [102] \\
\hline 2008 & Peptide 5 & VDCFLSRPTEKT & EL2 & EL2 & s-lipidation & HC \& GJ block & ND & [103-106] \\
\hline 2013 & SRPTEKT/GAP21 & SRPTEKT & $\begin{array}{l}\text { Cx32 } \\
\text { Cx43 }\end{array}$ & $\begin{array}{l}182-188 \\
204-210\end{array}$ & - & HC block & ND & {$[92,101]$} \\
\hline 2018 & $\begin{array}{l}\text { SRPTEKT-Hdc } \\
\text { (Gap21) }\end{array}$ & SRPTEKT-Hdc & Cx43 & EL2 & $\begin{array}{l}\text { Hexadecyl } \\
\text { (HC) lipid } \\
\text { moeity }\end{array}$ & HC \& GJ block & Y & {$[107,108]$} \\
\hline 2013 & $\begin{array}{l}\mathrm{C} 12-\mathrm{C} \times 43 \mathrm{MP} \\
\text { and } \\
\mathrm{C} 12-\mathrm{C} 12-\mathrm{C} \times 43 \\
\text { MP }\end{array}$ & $\begin{array}{c}\text { C12-VDCFLSRPTEKT } \\
\text { C12-C12- } \\
\text { VDCFLSRPTEKT }\end{array}$ & Cx43 & 199-210 & $\begin{array}{l}\text { 1/2 C12-Laa } \\
\text { moieties }\end{array}$ & HC block & ND & [109] \\
\hline \multicolumn{9}{|c|}{ Intracellular Loop (IL) } \\
\hline 2006 & $\begin{array}{l}{ }^{32} \mathrm{GAP} 24 \\
\text { TAT-GAP24 }\end{array}$ & $\begin{array}{c}\text { GHGDPLHLEEVKC } \\
\text { YGRKKRRQRRRGHGD } \\
\text { PLHLEEVKC }\end{array}$ & $\begin{array}{l}\text { Cx32 } \\
\text { Cx43 } \\
\text { Panx1 }\end{array}$ & $110-122$ & $+/-\mathrm{TAT}$ & $\begin{array}{c}\text { HC block } \\
\text { Inhibit GJ formation }\end{array}$ & ND & {$[10,110,111]$} \\
\hline 2004 & L2 (Cx43L2) & $\begin{array}{c}\text { DGVNVEMHL } \\
\text { KQIEIKKFKYGIEEHGK }\end{array}$ & Cx43 & 119-142 & - & $\begin{array}{l}\text { HC block, not GJ } \\
\text { GJ block }\end{array}$ & ND & {$[42,112,113]$} \\
\hline 2010 & TAT-L2 & $\begin{array}{c}\text { TAT-DGANVDMHL } \\
\text { KQIEIKKFKYGIEEHGK }\end{array}$ & Cx43 & 119-142 & TAT & HC block & ND & [114] \\
\hline 2013 & Gap19 & KQIEIKKFK & Cx43 & $128-136$ & - & HC block & ND & {$[111,115,116]$} \\
\hline 2014 & TAT-Gap19 & KQIEIKKFK & Cx43 & $128-136$ & TAT & HC block & ND & [117] \\
\hline 2020 & Xentry-Gap19 & KQIEIKKFK & Cx43 & $128-136$ & LCLRPV & HC block & & [118] \\
\hline 2010 & TAT-Cx50L2 & $\begin{array}{l}\text { GGERAPLAADQGS } \\
\text { VKKSSSSSKGTKK }\end{array}$ & Cx50 & $122-147$ & TAT & $\begin{array}{c}\text { ND Cx50, } \\
\text { No effect on Cx43 HC }\end{array}$ & ND & [114] \\
\hline & Gap 20 & EIKKFKYGC & Cx43 & $131-138$ & - & No effect & ND & [119] \\
\hline & Gap 22 & AELSCNKEVNG & Cx40 & 130-140 & - & No effect & ND & [92] \\
\hline \multicolumn{9}{|c|}{ N-terminus/C-terminus } \\
\hline 2005 & Alpha CT1 & RPRPDDLEI & $\mathrm{C} \times 43$ & $374-382$ & $\begin{array}{l}\text { Antenna- } \\
\text { pedia }\end{array}$ & $\begin{array}{c}\text { Promotes GJ } \\
\text { formation, enhance } \\
\text { GJ, } \\
\text { HC block }\end{array}$ & Y & [120-122] \\
\hline 2009 & $\begin{array}{c}\text { Alpha CT11 } \\
\text { aka (Alpha CT2) }\end{array}$ & RPRPDDLEI & Cx43 & 374-382 & None & $\begin{array}{c}\text { Promotes GJ } \\
\text { formation, enhance } \\
\text { GJ, } \\
\text { HC block } \\
\end{array}$ & Y & {$[122,123]$} \\
\hline 2009 & Alpha CT3 & $\begin{array}{l}\text { RQPKIWFPNRRKPWK } \\
\text { KRPSSRASSRASSR- } \\
\text { PRPDDLEI }\end{array}$ & Cx43 & 359-382 & $\begin{array}{l}\text { Antenna- } \\
\text { pedia }\end{array}$ & ND & ND & [122] \\
\hline 2010 & TAT-C $x 43 C T$ & SRPRPDDLEI & Cx43 & 373-382 & TAT & $\begin{array}{c}\text { Maintains open } \\
\text { channel and permits } \\
\text { dye transfer. Inhibits } \\
\text { HC block }\end{array}$ & ND & [114] \\
\hline 2011 & СТ9 & RPRPDDLEI & $\mathrm{C} \times 43$ & 374-382 & $+/-\mathrm{TAT}$ & HC block & $\mathrm{Y}$ & {$[101,124,125]$} \\
\hline 2013 & TAT-CT10 & SRPRPDDLEI & $\mathrm{C} \times 43$ & $373-382$ & TAT & $\begin{array}{l}\text { Inhibits the effect of } \\
\text { CxL2 peptides-stops } \\
\text { L2 hemichannel } \\
\text { blockade }\end{array}$ & ND & [115] \\
\hline
\end{tabular}


Table 1. Cont.

\begin{tabular}{|c|c|c|c|c|c|c|c|c|}
\hline \multirow{2}{*}{ Year } & \multirow{2}{*}{ Peptide } & \multirow{2}{*}{ Sequence/Formula } & \multicolumn{2}{|c|}{ Known Target Cx } & \multirow{2}{*}{ Linker } & \multirow{2}{*}{ Properties } & \multirow{2}{*}{$\begin{array}{c}\text { Increase } \\
\text { Cx43-PKC }\end{array}$} & \multirow{2}{*}{ Refs. } \\
\hline & & & $\mathrm{Cx}$ & Region & & & & \\
\hline \multicolumn{9}{|c|}{ N-terminus/C-terminus } \\
\hline 2010 & TAT-Cx50CT & SRARSDDLTV & Cx50 & $431-440$ & TAT & $\begin{array}{c}\text { ND-Cx50, } \\
\text { No effect on Cx43 HC }\end{array}$ & ND & [114] \\
\hline 2010 & ZP2519 & $\begin{array}{l}\text { AcRRK-(4 hydroxy } \\
\text { benzoyl) }\end{array}$ & $\begin{array}{c}\text { Cx43 } \\
\text { C-term }\end{array}$ & - & - & GJ opening & ND & [126] \\
\hline 2015 & $\begin{array}{l}\text { Juxtamembrane } \\
2 \text { (JM2) }\end{array}$ & VFFK-GVKDRVKGRSD & $\mathrm{Cx} 43$ & $231-245$ & $\begin{array}{l}\text { Antenna- } \\
\text { pedia }\end{array}$ & HC block & ND & [127] \\
\hline 2020 & $\begin{array}{l}\text { TAT-Cx43 } \\
266-283\end{array}$ & AYFNGCSSPTAPLSPMSP & $\mathrm{C} \times 43$ & $266-283$ & TAT & ND & ND & {$[128,129]$} \\
\hline
\end{tabular}

* indicates alterations through a GPCR pathway. Abbreviations used in the table: Cx-connexin; GJ—gap junction; HC—hemichannel; GPCR - G protein-coupled receptor; ND—not demonstrated; CT—carboxyl-terminus; EL—extracellular loop; IL—intracellular loop; NT-amino-terminus.

\section{Connexin-Mimetic Peptides}

Connexin-mimetic peptides differ from the AAP10 peptide derivatives in that they represent consensus amino acid sequence alignments for EL (1/2), IL, or CT regions of connexins (Figure 1). Connexin-mimetics initially were synthesized for use as epitopes for connexin antibody production $[130,131]$. The blocking antibodies raised using these peptides against the EL and IL domains of several connexins were tested as GJ blockers and demonstrated some effect in reducing dye transfer in chick embryos [116]. However, EL loop antibodies Gap7M (EL1/2), Gap11 (EL1/2 Cx32), Gap15 (IL of Cx43), and Gap17 (CT Cx40) were found to be ineffective in functional testing and were not able to reduce connexin-associated contractile responses in rabbit arterial tone [92]. Despite this, Dahl et al. described that peptides, used to generate antibodies, were effective in reducing Cx32 GJ formation and signaling in oocytes [132]. In 1995, Becker et al. found that connexin-mimetic peptides, mimicking the sequences of the IL domain, could effectively block GJ channels when directly injected into embryo cells [116]. In the subsequent decades, a number of connexin-mimetic peptides have been generated and tested with a multitude of proposed functions including blockade of hemichannel and GJ signaling, alterations in GJ formation, and disruption of protein localization and protein-protein interactions (Table 1). While a few pathways of action have been identified, many of these peptides still function through unknown mechanisms.

\subsection{Connexin-Mimetic Peptides That Target the Extracellular Loops}

Connexin targeting peptides were initially designed with sequence homology to the EL regions of the protein, with the intent of direct peptide-protein binding and subsequent GJ channel blockade [54,92]. Exactly why the connexin-mimetic peptides would bind in this way has not been well described, but it was assumed that they could act to inhibit normal protein interactions or docking functions of hemichannels to GJs, thus blocking hemichannel opening, GJ formation, and/or GJ signaling $[54,123,133]$.

The early peptides targeting the EL-Gap21, Gap26, Gap27, and "Peptide 5" (a peptide shifted by 5 amino acids towards the amino-terminus of Gap27)—were designed against EL1 and EL2 of Cx32 and Cx43 (Table 1) [92,134]. Peptides targeting the EL of Cx32 (Gap21) were shown to delay GJ formation and electrical synchronization in chick cardiomyocytes [134]. Gap26 and Gap27 peptides effectively reduce Cx43 GJ and hemichannel functions $[135,136]$. Peptide 5, described by O'Carroll et al. [103], is reported to block hemichannel functions with effects in neuroprotection following spinal cord injuries, vascular leak, and ischemia [104-106,137]. In rabbit arterial sections, Gap21, Gap26, and Gap27 reduce phenylephrine-induced vasoconstriction [92].

Given the proposed consensus peptide-protein binding mechanism, it was presumed that the connexin-mimetics would be highly specific. For example, the Gap26 peptide sequence, VCYDKSFPISHVR, corresponds to amino acids 64-76 of Cx43-EL1. However, this peptide also altered the channel functions of $\mathrm{Cx} 32, \mathrm{Cx} 37$, and $\mathrm{Cx} 40$ in a wide range 
of tissues [54]. This appears to result from the highly conserved nature of connexin sequences in the EL regions $[94,96,138]$. For example, Gap26 has 100\% homology with human Cx43-EL (accession CAG46461), but also greater than 75\% similarity with Cx40EL (accession NP_005257), Cx32-EL (accession NP_001091111), and Cx37-EL (accession number NP_002051.2). Studies by Warner et al. suggested that key peptide amino acid motifs SHRV and SRPTEK, found in many connexin EL1 and EL2 loops, may play a dominant role in channel blockade [92,134]. It is possible then, that these sites are critical for peptide-protein binding, which potentially limits connexin specificity.

Peptides that are reportedly more specific, targeting Cx32, Cx37, Cx40, and Cx43, were later developed by adjusting the amino acid sequences within Gap26 and Gap27 to produce ${ }^{37,40} \mathrm{Gap} 26,{ }^{43} \mathrm{Gap} 26(\mathrm{M}),{ }^{32} \mathrm{Gap} 27,{ }^{40} \mathrm{Gap} 27$, and ${ }^{37,43} \mathrm{Gap} 27$ (Table 1) [94]. Most recently, ${ }^{62} \mathrm{Gap} 27$ has also been designed and tested for the inhibition of Cx62 in platelets, with no reported cross-talk with Cx40 and Cx37 hemichannels [102]. ${ }^{43}$ Gap26 and ${ }^{37,43}$ Gap27 have wide-ranging effects reported in many tissues including the inhibition of acetylcholine responses in smooth muscle cells, reduced dye transfer in cultured cells [139], accelerated migration and wound closure in fibroblasts, keratinocytes, and epithelial cells [46,140,141], and limited ischemic damage following injury in hearts [142]. The design of ${ }^{40} \mathrm{Gap} 27$ only differs from the ${ }^{37,43}$ Gap27 by three amino acids and still contains the SRPTEK motif $[93,94,100,143]$. Several studies suggest that ${ }^{40}$ Gap27 is specific to Cx40 GJs but not Cx43 or Cx37 [93,100,139]. ${ }^{40}$ Gap27 does not inhibit dye transfer in COS-7 fibroblasts that express $\mathrm{C} \times 43$ and not $\mathrm{C} \times 40$, demonstrating that the ${ }^{40} \mathrm{Gap} 27$ peptide does not regulate Cx43 $[93,100]$. The addition of lipid alkyl groups (C12-Laa) increased peptide stability of a short region of the GAP27 peptide by around 2 fold [109]. This was further adapted by incorporating a hexadecyl lipid moiety (C16 lipid, hexadecyl-NH2; Hdc) at the CT of "Peptide 5" and GAP27 peptides to produce SRPTEKT-Hdc [107,108]. SRPTEKT-Hdc is reported to block hemichannels and GJs, as measured by inhibition of hemichannel dye uptake (opening) and reduced $\mathrm{Ca}^{2+}$ wave propagation [107,108].

Gap26 and Gap27 peptides, and their iterations, have been shown to increase intracellular $\mathrm{Ca}^{2+}$ concentrations, similar to observations following treatments with the non-selective GJ blocker glycyrrhetinic acid in cultured endothelial cells and smooth muscle cells $[100,101]$. The peptides desynchronized $\mathrm{Ca}^{2+}$ transients in cultured cells and rat mesenteric arteries associated with reductions in vasomotion [101,144]. In cultured endothelial cells and smooth muscle cells, ${ }^{37,40} \mathrm{Gap} 26$ and ${ }^{40} \mathrm{Gap} 27$ inhibited GJ-based dye transfer, but did not alter synthesis or de novo formation of GJ plaques at concentrations up to $600 \mu \mathrm{M}$ [100]. However, later studies suggested that this may be cell type-specific, as Gap27 decreases transcription and protein expression of Cx43 in juvenile dermal fibroblasts [46].

Both Gap 26 and Gap27 peptides induce PKC phosphorylation of Cx43-S368, associated with reduced GJ signaling $[95,108,145,146]$. The EL2 peptide SRPTEKT-hdc (containing the same Cx sequence as Gap21 [92]) blocked GJ function, which is also related to increased PKC-associated Cx43-S368 phosphorylation $[107,108]$. Treatments with ${ }^{62}$ Gap27 also activate protein kinase A (PKA) pathways in platelets, although it is not currently clear if this has a direct effect on the Cx62 protein phosphorylation [102].

It is still not clear how the EL-targeting peptides function. To our knowledge, no conclusive studies have shown direct binding of the EL-targeting peptides with their corresponding connexin sequences. A recent blind docking molecular mechanics modeling approach studying Gap26, Gap27, and "Peptide 5" suggests that the peptide binding site may be unrelated to the connexin-mimetic sequence [147]. Simon et al. suggested that, due to a number of factors including a lack of access to the sites, binding most likely occurs within the inner EL1 surface and EL1-2 interface [147]. Wang et al. also suggested that peptide size may play a role in the inhibition of connexin channels, potentially leading to steric hindrance of the channel [10], although this has been debated for other peptides [115].

The idea of channel block in this manner has been discussed in detail [138], but there is little direct evidence for this mechanism. Gap26 and Gap27 peptides are around 
1300-1500 Da in size, and there is evidence to suggest that peptides up to 1800 Da can enter via connexin hemichannels [148]. This leads to the possibility that EL peptides can target protein sites distinct from the EL regions as other connexin-mimetic peptides have been found to bind multiple regions of the same connexin protein [123].

\subsection{Connexin Mimetic Peptides That Target the Intracellular Loop}

A model for the control of GJ (Cx43 and Cx40) channel gating was suggested in studies by Delmar and colleagues, where they described a "ball-and-chain" gating mechanism [149-152]. Their model identified a pH-dependent interaction of the flexible connexinCT with a portion of the connexin-IL $[149,151,153]$. Based on these studies it was proposed that the connexin-IL acts as a receptor site for regulation of the GJ pore, in that, binding at this site by connexin-CT leads to closure of the channel [154]. Using protein interaction studies (ELISA, NMR) based techniques, Delmar et al. identified a connexin-mimetic peptide of the Cx43-IL that binds the Cx43CT, later described as the L2/Cx43L2 peptide (Table 1) [42]. In vitro studies of purified proteins demonstrated that the Cx43L2 peptide and $\mathrm{Cx} 43-\mathrm{CT}$ directly interact in a $\mathrm{pH}$-dependent manner [42].

There is very little sequence homology in the connexin-IL, unlike the -EL regions, therefore peptides are presumably isoform-specific. Early peptide studies targeting the Cx43-IL, using peptides within the L2 region, GAP 13 and GAP 15 peptides, required direct injection of the peptides into cells to produce a functional block, due to the inability of the peptide to cross the plasma membrane [116]. Since then, many studies have linked cell-penetrating moieties that permit the membrane translocation of peptides. The most commonly used forms of these in connexin-mimetic peptide studies has been the HIV-TAT sequence (YGRKKRRQRRR) [153,155], antennapedia sequence (RQPKIWFPNRRKPWKK) [156], and the cell-penetrating peptide sequence (LCLRPV) derived from the X-protein of hepatitis B virus [118], added to the NT or CT of each peptide (Table 1). Several studies have demonstrated the effectiveness of these approaches in permitting the internalization of the connexin mimetic peptides [114,117,121].

To test the functions of the IL-CT interaction in the role of GJ coupling or hemichannel signaling outside of structural studies, several other L2 peptides were developed by Leybaert and colleagues with an attached TAT sequence [114]. In these studies, the authors developed TAT-bound peptides for the Cx50L2 (TAT-Cx50L2) as well as CT peptides for Cx43 and Cx50 (TAT-Cx43CT, TAT-Cx50CT, Table 1). TAT-Cx50L2 peptides produced no effect [114], and the function of the TAT-Cx43CT/-Cx50CT peptides will be discussed in detail later. The studies using TAT-Cx43L2 are reported to be specific to hemichannel functions, indicating that there are differential regulatory pathways for GJ gating [114].

The Gap19 peptide, consisting of 9 amino acids within the Cx43L2 region, was described to alter $C \times 43$, but not $C \times 40$ hemichannels, preventing experimentally induced ischemia-reperfusion injury [115], and Cx43 hemichannel function in astrocytes [117]. The first Gap19 iteration, with a molecular weight of around $1100 \mathrm{Da}$ and net charge of +3, was not attached with a specific internalization sequence, rather it was assumed the "KKFK" sequence permitted plasma membrane translocation as previously described [157]. Later, a TAT-bound Gap19 (TAT-19) was shown to have anti-inflammatory and neuroprotective effects [158]. TAT-Gap19 (Cx43), as well as TAT-GAP24 (same L2 region in Cx32), both block hemichannels reducing acetaminophen-induced liver injury [111], limiting $\mathrm{Ca}^{2+}$ activated hemichannel activation, and reducing arrhythmias in human heart tissues [159]. Recently, Coutinho et al. developed Xentry-Gap19, which is composed of Gap19 bound by the cell-penetrating "LCLRPV" peptide sequence, using Syndecan-4 for entry, potentially making it specific to cells expressing this receptor [118]. Xentry-Gap19 provides a greater hemichannel block than the Gap19 peptide alone, while not altering GJ signaling [118].

The Gap 19 and Cx43L2 peptides can directly bind the Cx43-CT. Ponsaerts et al. identified binding between the Cx43L2 peptide and the Cx43CT peptide containing the last 10 amino acids of Cx43, using surface plasmon resonance (SPR) analysis [114]. Further, Ponsaerts et al. determined that amino acids isoleucine (I130) and histidine (H126) are 
essential for peptide functions and hemichannel blockade. Interaction studies by Wang et al., using SPR, determined that GAP19, like Cx43L2, interacts with amino acids between 255-382 on the Cx43-CT [115]. SPR data suggest that GAP19 has a stronger interaction with the $\mathrm{C} \times 43-\mathrm{CT}^{255} \mp 382$ than the Cx43L2 peptide [115]. However, the Cx43CT protein used in these studies was longer (127 a.a.) than that used for the Ponsaerts SPR data (10 a.a.) [114], which may indicate different binding modalities or regions for Cx43-CT. A 9 a.a. peptide, Gap20, overlaps Gap19 and includes a.a. I130, but not H126, is biologically inactive and does not alter cellular signaling. Gap20 and another peptide, Gap22 (Cx40-L2 region), were ineffective against the phenylephrine-induced $\mathrm{Ca}^{2+}$ oscillations on rabbit arterial sections and vasoconstriction in rat mesenteric arteries [92,119]. Early et al. described a slight depolarization of the rat mesenteric arteries by Gap20, potentially as a result of high peptide concentrations of $300 \mu \mathrm{M}$ [119]. While these experiments did not include the use of internalization sequences, their small size and charge could potentially allow for uptake through connexin hemichannels (as previously suggested [157]) which may account for these effects.

\subsection{Connexin-Mimetic Peptides That Target the Carboxyl-Terminus}

The intracellular $\mathrm{CT}$ regions of connexin proteins regulate a number of functions including, but not limited to, protein trafficking, assembly, and channel gating [160-162]. The connexin-CT is also known as a regulator of cell growth and differentiation that interacts with a number of proteins within the cell [162]. Given the critical connexin functions regulated by the $\mathrm{CT}$, the region has been an attractive target for peptide therapies.

\subsection{1. $\alpha$. CT Peptides}

The first biologically active peptide targeting the Cx43 CT was reported in 2005 by the Gourdie laboratory [121]. The alpha carboxyl terminus $1(\alpha \mathrm{CT} 1)$ peptide is a mimetic sequence to the last nine amino acids of the CT of Cx43 (RPRPDDLEI), attached to a 16-amino acid antennapedia sequence for cell internalization, linked to the peptide's $\mathrm{N}$ terminus [121]. Direct protein-peptide interactions have been demonstrated for $\mathrm{Cx} 43$ and $\alpha \mathrm{CT} 1$, interacting with the $\mathrm{Cx} 43-\mathrm{CT}, \mathrm{Cx} 43-\mathrm{L} 2$ domains, the second alpha-helical region of the Cx43-CT (H2; Figure 1), and the PDZ2 binding domain of zona occludins 1 (ZO1) [123].

As described above, treatment with $\alpha \mathrm{CT} 1$ increases phosphorylation at Cx43-S368 in cultured HeLa cells [120,122]. Further, in cell culture, $\alpha$ CT1 has been shown to inhibit binding with its protein partner ZO1 [163]. Under physiological conditions, the PDZ2 domain of ZO1 has been shown to interact with the Cx43 CT and studies have demonstrated that ZO1 regulates the connexin to GJ transition, by slowing the rate at which hemichannels move into established GJ plaques [163-165]. Further, $\alpha$ CT1 treatment has been shown to increase GJ plaque size and GJ coupling, and decrease hemichannel activity [163]. At the organ level, $\alpha \mathrm{CT} 1$ increases wound closure rates, reduces scarring, and reduces inflammation in the skin and retinal wounds [166]. In hearts, $\alpha \mathrm{CT} 1$ has been proven effective in mitigating ischemia-reperfusion injury in murine models and has antiarrhythmic effects [123]. To date, the $\alpha \mathrm{CT} 1$ peptide has shown promising results as a therapy for a variety of conditions at the pre-clinical and clinical levels, including cardiac disease, retinal injury, and wound healing; recently reporting successful phase II clinical trial data on the use of $\alpha \mathrm{CT} 1$ for the treatment of venous leg ulcers and diabetic foot ulcers [48,53,167-171].

Several peptide modifications of $\alpha \mathrm{CT} 1$ also exist. The $\alpha \mathrm{CT} 2$ (also referred to as $\alpha \mathrm{CT} 11$ ) [123] peptide consisting of the last nine amino acids of Cx43, but without an antennapedia sequence, and the $\alpha \mathrm{CT} 3$ peptide consisting of the last $23 \mathrm{Cx} 43-\mathrm{CT}$ amino acids with an antennapedia sequence were found to accelerate wound healing in mice [122]. Though, both peptides were less effective than $\alpha \mathrm{CT} 1$. The $\alpha \mathrm{CT} 11$ peptide has recently been shown to be cardioprotective against ischemia-reperfusion injury, preserving left ventricular developed pressure after injury associated with increases in Cx43-S368 phosphorylation [123]. 


\subsubsection{CT9 Peptide/CT10/TAT-Cx43 Peptides}

Over the last decade, Leybaert and colleagues have published extensively on a peptide referred to as CT9, which is comprised of the same last 9 amino acids of the Cx43 CT found in the $\alpha$ CT11 peptide (Table 1) [101]. Supporting the earlier findings from the Gourdie laboratory's work with $\alpha \mathrm{CT} 11, \mathrm{CT} 9$ was found to block Cx43-ZO1 interactions and to trigger PKC-mediated Cx43-S368 phosphorylation $[123,125]$. In contrast to earlier works on $\alpha \mathrm{CT} 11$, where several studies demonstrated the $\alpha \mathrm{CT}$ peptides to block connexin hemichannels [122,172,173], CT9 is reported to acutely activate Cx32 and Cx43 hemichannels [101]. One important difference that may explain these discrepancies is that the $\alpha \mathrm{CT} 11$ effect on hemichannels has been reported over hours or even days, whereas the effect of CT9 was measured over seconds to minutes. This could suggest a potential difference in short- and long-term peptide treatments to the hemichannel activation/inactivation axis.

Several other studies have described the effects of two identical peptides covering the last 10 a.a. of the Cx43-CT, referred to as TAT-Cx43CT [114] and TAT-CT10 [115]. TATCx43CT maintains hemichannel opening, allowing for the preservation of coordinated $\mathrm{Ca}^{2+}$ signaling in endothelial cells [114]. In their studies, Ponsaerts et al. demonstrated binding between Cx43CT and the PDZ2 domain of ZO-1 by SPR, with binding lost when using the TAT-Cx43CT $\triangle \mathrm{I}$ peptide that is lacking the last isoleucine [114]. However, ZO1-Cx43CT interaction did not alter peptide-linked hemichannel functions in these studies [114]. Both TAT-CX43CT and TAT-CT10 peptides maintain hemichannel opening, in the presence of Cx43 hemichannel blocker peptides TAT-L2 (Cx43) and GAP19 [114,115]. This is thought to occur by peptide disruption of GAP19 binding the Cx43-CT [115]. Ponsaert et al. used SPR to demonstrate that Cx43-L2 and Cx43-CT peptides interact, suggesting that inhibition may occur by competition for binding sites on the Cx43-L2 region [114]. Studies by Wang et al., produced similar results with SPR analysis demonstrating binding between GAP19 peptide and the Cx43-CT (a.a. 255-382) and the Cx43-IL (a.a. 119-144). Although these studies did not directly demonstrate inhibition/ competition for binding by the TAT-CT10 peptide [115].

\subsubsection{TAT-Cx43 266-283 Peptide}

SRC tyrosine kinases are involved in numerous cell functions, including cell metabolism, and are found in both proliferating and postmitotic cells. The protein exists in both a cellular form (cSRC) and as an oncogenic viral homolog (vSRC) [174]. Interaction between SRC and $\mathrm{Cx} 43$ has been demonstrated to occur at the Src homology 2 (SH2) and Src homology 3 (SH3) domains [175]. cSRC binding with the Cx43-CT results in the inhibition of cSRC. Active cSRC plays a role in perpetuating cancer cell proliferation including in glioma stem cells. Work from the Tabernero laboratory identified a $\mathrm{Cx} 43$ peptide spanning amino acids 266 to 283 (TAT-Cx43 266-283) that mimics the SRC SH3 binding domain along with a number of upstream residues [176]. This peptide contains a cell-penetrating TAT sequence allowing it to enter the intracellular space and bind CSRC, resulting in CSRC inactivation [176]. In cultured glioblastoma stem cells, obtained from patients, the application of TAT-Cx43 266-283 reduced cSRC activity and limited the glioblastoma phenotype [176]. TAT-Cx43 266-283 treatment in both in vivo mouse models and cultured human glioblastoma stem cells resulted in a reduction in glucose uptake and consumption. This effect was mediated by the inactivation of cSRC and a subsequent reduction in hexokinase-2 (HK-2), glucose-6-phosphate dehydrogenase (G6PD), and glucose transporter-3 (GLUT-3) proteins, all of which are involved in the proliferation of glioblastoma stem cells through the uptake and usage of glucose [128].

In neural progenitor cells, cSRC is involved in survival and proliferation via the epidermal growth factor (EGF) and fibroblast growth factor 2 (FGF-2) signaling pathways $[177,178]$. These progenitor cells, when treated with the Cx43 266-283 peptide in culture, exhibited impaired survival, proliferation, and differentiation rates due to cSRC inhibition. Interestingly, the TAT-Cx43 266-283 peptide increased rates of astrocyte prolifer- 
ation in culture. The authors hypothesized that this is due to reductions in cSRC leading to a decrease in $\beta$-catenin expression by an unknown mechanism [129].

The interaction between Cx43 and cSRC has also been studied in the context of neuroinflammation. In response to neuroinflammation stimuli, TAT-Cx43 266-283 reduced cSRC levels and exhibited a neuroprotective effect [179]. In these studies, it was proposed that TAT-Cx43 266-283 induced cSRC inhibition interferes with the ability of activated astrocytes to mount an inflammatory response to neuronal injury. Astrocytic hemichannels, including Cx43, were inhibited by TAT-Cx43 266-283 indicating that cSRC mediates hemichannel activation [179].

\subsubsection{JM2 Peptide}

The Cx43 juxtamembrane 2 (JM2) connexin-mimetic peptide, published by Calder et al. in 2015, was designed to target amino acids 231-245 of the Cx43 CT, a known microtubulebinding domain [127]. Initial studies found that JM2 treatment significantly enhanced the Cx43- $\beta$-tubulin interaction thought to be important for Cx43 trafficking. Yet, paradoxically reduces cell surface Cx43 expression and GJ size [180]. Likewise, JM2 decreased GJ and hemichannel activity, as assessed by ATP release assay [127]. In a subsequent study, Rhett et al. speculated that decreased Cx43 channel activity resulted from enhanced Cx43- $\beta$ tubulin interactions, which led to $\mathrm{Cx} 43$ inappropriately 'adhering' to the microtubules as opposed to using them as a trafficking scaffold [23].

In vivo studies in mice and rats demonstrate that JM2 treatment reduces inflammatory cell infiltration following submuscular device implant [127], reduces tumor recurrence following solid tumor resection, and improves wound healing [180]. Further studies have shown that JM2 promotes tumor cell apoptosis in cultured B16F10 and Skov-3 tumor cells and improves the migration of cultured endothelial cells [180]. Recent research yielded promising results testing JM2 as a therapy for glioblastoma and there are currently groups looking to use JM2 loaded biodegradable nanoparticles to treat temozolomide resistant glioblastoma, with studies in preparation for clinical trials [181,182].

\section{The Phosphorylation Phenomenon: Cx43-S368-Phosphorylation as a Key Factor in the Effect of Connexin Mimetic Peptides}

One observation that bears mentioning in this review is the consistency with which Cx43 peptides induce PKC-associated Cx43-S368 phosphorylation (Table 1). Many of the Cx43 targeting peptides in this review, regardless of site-specificity to the EL, IL, or CT, appear to cause intrinsic changes in Cx43 phosphorylation. Phosphorylation of Cx43-CT is a key event in channel open/close probability but is also a significant modulator of protein-protein interactions that control protein trafficking and localization as well as non-GJ functions.

There is conflicting information on whether Cx43 PKC-phosphorylation leads to enhanced or reduced GJ coupling [81,158]. Phosphorylation of Cx43 by PKC is reported primarily at Cx43-S368, though five other sites are also reported to be altered, thus it is possible combinations of these phosphorylation sites may occur [81]. Phosphorylation of Cx43-S368 alters the random coil nature of the Cx43-CT and induces a more alpha-helical state, associated with reduced GJ formation and signaling $[146,183,184]$. Phosphorylation by PKC is also reported to alter the nature of Cx43 interactions with ubiquitin ligases and thus its degradation within the cell [185]. While PKC phosphorylation is generally associated with the closure of the gap junctions $[146,186]$, several studies have found that peptide treatments (e.g., $\alpha \mathrm{CT} 1$ ) enhance $\mathrm{PKC} \varepsilon$ phosphorylation of $\mathrm{Cx} 43$, leading to increased gap junction stability and communication, but reduced hemichannel opening $[125,163]$. Similarly, the non-targeting peptides such as AAP10 and danegaptide, all increase Cx43-S368 phosphorylation, presumably through GPCR activation, which is reported to increase gap junction communication $[65,72,78,82-84]$. As noted by Jiang et al. the $\alpha \mathrm{CT} 1$ and $\alpha \mathrm{CT} 11$ peptides can interact with multiple regions on the Cx43 protein, and with other proteins, which may result in an alteration in accessibility of specific $\mathrm{Cx} 43$ amino acids. This may indicate that peptides altering the CT/L2 regions leaving the Cx43-S368 region more 
susceptible to phosphorylation [123]. Thus, it is possible that connexin mimetic peptide binding induces phosphorylation by altering the structure restraints of the $\mathrm{Cx} 43-\mathrm{CT}$ or by promoting phosphorylation combinations of the multiple suggested Cx43-PKC sites, which can result in both increased or decreased gap junction coupling [81].

The overall significance of the Cx43-PKC (S368) phosphorylation following peptide treatments remains to be fully elucidated. As described, many studies have found that peptide-induced Cx43-PKC phosphorylation was associated with improved outcomes, such as mitigated ischemic injury, reduced cellular proliferation in cancer, and improved wound healing. Thus, while highly speculative, it is possible that activating the PKC pathways may be considered cytoprotective.

\section{Connexin Peptide Cross-Reactivity with Pannexins}

The "Gap" peptides have shown promise of increased specificity to connexins by comparison to conventional channel blockers such as glycyrrhetinic acid [187]. However, there are serious concerns that they may target related channels and produce off-target effects. Recently, ${ }^{43}$ Gap27 and ${ }^{32}$ Gap24 have been found to block pannexin 1 (Panx1) channels at concentrations ranging from $200 \mu \mathrm{M}$ to $2 \mathrm{mM}$ [10]. This has led some to debate whether the connexin-mimetic peptides are truly sufficiently selective to allow for specific channel identification [10,187]

Pannexins form purine release channels that are structurally homologous to the connexins, containing four transmembrane domains, two EL, and cytoplasmic NT, IL, and $\mathrm{CT}$ but share little sequence homology. While connexins channels are known to form as hexamers, recent data has shown that Panx1 channels oligomerize as heptamers $[188,189]$. The pannexin channels function similarly to that described for connexin hemichannels and are known to release ATP as well as other molecules [190]. Several GJ blockers and non-specific channel blockers inhibit both connexin and pannexin channel release of ATP. This poses a complication with data interpretation, as measures of ATP release, used to assess connexin hemichannel function, are a shared output associated with alterations in pannexin channel activity.

Connexin-mimetic peptides have demonstrated effects on pannexin channels. These peptides are known to attenuate ATP release and $\mathrm{Ca}^{2+}$ waves, associated with both connexin and pannexin channels. Both ${ }^{37,43} \mathrm{Gap} 27$ and ${ }^{32} \mathrm{Gap} 24$ can reversibly inhibit pannexin membrane currents [10]. ${ }^{37,43}$ Gap27 contains a sequence from an extracellular loop of Cx43, while ${ }^{32} \mathrm{Gap} 24$ contains a sequence from the Cx32-IL. Interestingly, scrambled ${ }^{32} \mathrm{Gap} 24$ showed similar levels of inhibition to its non-scrambled counterpart. Polyethyleneglycol 1500 (PEG 1500), an inert, biocompatible polymer inhibited pannexin channels similarly to the connexin-mimetic peptides. This along with the inhibitory activity of scrambled ${ }^{32}$ Gap24 peptides suggests inhibition of pannexins by mimetic peptides may function via steric block of the channel rather than peptide-protein interactions [10].

Multiple Panx1 mimetic peptides have been developed targeting sequences on both the intracellular and extracellular loops. Peptides E1a, E1b, E1c, E2a, and E2b target Panx1EL sequences. Both E1b and E1c can inhibit Panx1 channels by more than $10 \%$, with E1b having the strongest inhibitory effect. The peptide 10Panx1 contains the same sequence as E1b but is three amino acids shorter. Both 10Panx1 and E1b inhibit Panx1 channels to a similar extent [10]. Other Panx1 peptide inhibitors include PxIL2P that targets the Panx1-IL2 region developed by Isakson et al. [191,192], and an interfering peptide Panx Y308, which has a target sequence between a.a. 305 and 318 on the Panx 1-CT developed by the Thompson lab [193,194].

The peptide 10Panx1 inhibits Panx1 currents compared with its scrambled sequence, suggesting specificity [195-197]. However, 10Panx1 has also been found to inhibit Cx46 channels [10]. PxIL2P reportedly targets a Panx1 sequence necessary for Panx1 activation by alpha 1 andenosine receptor signaling [192]. Application of PxIL2P significantly decreases phenylephrine-induced smooth muscle cell constriction in C57BL/6 mice. These effects were similar to those observed in smooth muscle cell-specific Panx1 knockout mice, 
suggesting that PxIL2P is at least somewhat specific to Panx1 channels [192]. Panx Y308 was created specifically to target the Panx1 Src family kinases (SFK) consensus-like sequence between Panx1 305 and 318. This sequence contains a site at tyrosine Y308 where SFK is believed to phosphorylate Panx1 and causes channel opening in anoxic conditions. Panx Y308 has been shown to attenuate anoxic depolarization of Panx1 [193].

\section{Concluding Remarks-Clinical Applications and Future Approaches}

In the last 25 years, several encouraging lines of evidence have demonstrated that connexin targeting peptides can improve disease outcomes in pre-clinical models of disease. Connexin proteins are attractive therapeutic targets given their prevalence in disease, although approaches to target connexins are complicated due to the ubiquitous distribution of the proteins in most tissues. Inappropriately reducing the expression of connexins or inhibiting GJ functions can be lethal. Alterations or mutations in vasculature-associated connexins, such as Cx37 and Cx40, lead to disturbances in blood vessel relaxation and have knock-on effects in other systems leading to alteration in renin secretion and increases in blood pressure. Genetic connexin mutations in humans are rare, but several have been identified. Mutations in Cx43 have been linked with cardiovascular disease [198-202], and Cx26 mutations lead to sensorineural hearing loss [203,204] and keratoderma [205,206]. As a result, systemically targeting reductions in connexin expression provides fairly limited options due to the potential for side effects. However, a greater understanding of diseaseassociated, and potentially redundant mechanisms may help provide avenues for future therapeutic intervention.

At present, the instability of peptides severely limits their therapeutic potential. Most peptides have a half-life of seconds to minutes and are quickly degraded by changes in $\mathrm{pH}$, shifts in temperature, and peptidases, making systemic delivery challenging at best [207]. Chen et al. added the lipid-alkyl groups (C12-Laa) moieties to extended GAP27 peptides increasing half-life from $145 \mathrm{~min}$ to around $350 \mathrm{~min}$, which could increase their therapeutic viability [109]. Protecting the peptides from peptidases is another potential option, and can be accomplished through peptide cyclization. This has the advantage of decreasing enzyme breakdown but may also limit targeting of the peptides by limiting access to active sites and blocking structural-based interactions [123]. Cyclization may also be limited in peptides containing cysteines, which are found in connexin CT and EL, as they must be removed for the production of disulfides bonds during peptide cyclization.

Likely, future therapeutic approaches may also require systemic delivery by encapsulation of peptides (such as in exosomes [208]), in a process that allows for tissue-specific, and intracellular targeting of the connexin proteins. There is still a general lack of detail on the overall peptide mechanisms that produce their effects. Greater examination of the molecular pathways underlying the peptide effects could help define more specific therapeutics directed at the connexin proteins and their functions and may also allow for the development of peptide-based therapeutics such as small molecule discovery or single domain antibodies targeting these regions.

Author Contributions: D.R.K.; M.W.S.; X.L.; J.X.; S.L.; M.K.; B.E.I.; S.R.J. writing, draft preparation, review, and editing. All authors have read and agreed to the published version of the manuscript.

Funding: This research was funded by AHA-CDA 19CDA34630036 (S.R.J.), NIH R01-AA025854 (M.K.), NIH R01-HL137112 (B.E.I., M.K.).

Acknowledgments: We thank Anita Impagliazzo for the illustration.

Conflicts of Interest: The authors declare no conflict of interest.

\section{References}

1. Revel, J.P.; Karnovsky, M.J. Hexagonal array of subunits in intercellular junctions of the mouse heart and liver. J. Cell Biol. 1967, 33, C7-C12. [CrossRef]

2. Dewey, M.M.; Barr, L. Intercellular Connection between Smooth Muscle Cells: The Nexus. Science 1962, 137, 670-672. [CrossRef] 
3. Robertson, J.D. The occurence of a subunit pattern in the unit membranes of club endings in mauthner cell synapses in goldfish brains. J. Cell Biol. 1963, 19, 201-221. [CrossRef]

4. Evans, W.H.; Martin, P.E. Gap junctions: Structure and function (Review). Mol. Membr. Biol. 2002, 19, 121-136. [CrossRef]

5. Johnstone, S.; Isakson, B.; Locke, D. Biological and biophysical properties of vascular connexin channels. Int. Rev. Cell Mol. Biol. 2009, 278, 69-118. [CrossRef]

6. Koval, M.; Molina, S.A.; Burt, J.M. Mix and match: Investigating heteromeric and heterotypic gap junction channels in model systems and native tissues. FEBS Lett. 2014, 588, 1193-1204. [CrossRef] [PubMed]

7. Weber, P.A.; Chang, H.C.; Spaeth, K.E.; Nitsche, J.M.; Nicholson, B.J. The permeability of gap junction channels to probes of different size is dependent on connexin composition and permeant-pore affinities. Biophys. J. 2004, 87, 958-973. [CrossRef] [PubMed]

8. Santa Cruz, A.; Meşe, G.; Valiuniene, L.; Brink, P.R.; White, T.W.; Valiunas, V. Altered conductance and permeability of Cx40 mutations associated with atrial fibrillation. J. Gen. Physiol. 2015, 146, 387-398. [CrossRef] [PubMed]

9. Kanaporis, G.; Brink, P.R.; Valiunas, V. Gap junction permeability: Selectivity for anionic and cationic probes. Am. J. Physiol. Cell Physiol. 2011, 300, C600-C609. [CrossRef]

10. Wang, J.; Ma, M.; Locovei, S.; Keane, R.W.; Dahl, G. Modulation of membrane channel currents by gap junction protein mimetic peptides: Size matters. Am. J. Physiol. Cell Physiol. 2007, 293, C1112-C1119. [CrossRef]

11. Zhu, Y.; Chen, X.; Lu, Y.; Fan, S.; Yang, Y.; Chen, Q.; Huang, Q.; Xia, L.; Wei, Y.; Zheng, J.; et al. Diphenyleneiodonium enhances P2X7 dependent non-opsonized phagocytosis and suppresses inflammasome activation via blocking CX43-mediated ATP leakage. Pharmacol. Res. 2021, 166, 105470. [CrossRef] [PubMed]

12. Orellana, J.A.; Froger, N.; Ezan, P.; Jiang, J.X.; Bennett, M.V.; Naus, C.C.; Giaume, C.; Sáez, J.C. ATP and glutamate released via astroglial connexin 43 hemichannels mediate neuronal death through activation of pannexin 1 hemichannels. J. Neurochem. 2011, 118, 826-840. [CrossRef] [PubMed]

13. Huckstepp, R.T.; id Bihi, R.; Eason, R.; Spyer, K.M.; Dicke, N.; Willecke, K.; Marina, N.; Gourine, A.V.; Dale, N. Connexin hemichannel-mediated $\mathrm{CO}_{2}$-dependent release of ATP in the medulla oblongata contributes to central respiratory chemosensitivity. J. Physiol. 2010, 588, 3901-3920. [CrossRef] [PubMed]

14. Turovsky, E.A.; Varlamova, E.G. Mechanism of $\mathrm{Ca}^{2+}$-Dependent Pro-Apoptotic Action of Selenium Nanoparticles, Mediated by Activation of Cx43 Hemichannels. Biology 2021, 10, 743. [CrossRef] [PubMed]

15. Turovsky, E.A.; Braga, A.; Yu, Y.; Esteras, N.; Korsak, A.; Theparambil, S.M.; Hadjihambi, A.; Hosford, P.S.; Teschemacher, A.G.; Marina, N.; et al. Mechanosensory Signaling in Astrocytes. J. Neurosci. 2020, 40, 9364-9371. [CrossRef]

16. Turovsky, E.A.; Varlamova, E.G.; Turovskaya, M.V. Activation of Cx43 Hemichannels Induces the Generation of Ca ${ }^{2+} \mathrm{Oscillations}$ in White Adipocytes and Stimulates Lipolysis. Int. J. Mol. Sci. 2021, 22, 8095. [CrossRef] [PubMed]

17. Pecoraro, M.; Sorrentino, R.; Franceschelli, S.; Del Pizzo, M.; Pinto, A.; Popolo, A. Doxorubicin-Mediated Cardiotoxicity: Role of Mitochondrial Connexin 43. Cardiovasc. Toxicol. 2015, 15, 366-376. [CrossRef] [PubMed]

18. Fowler, S.L.; Akins, M.; Zhou, H.; Figeys, D.; Bennett, S.A. The liver connexin 32 interactome is a novel plasma membranemitochondrial signaling nexus. J. Proteome Res. 2013, 12, 2597-2610. [CrossRef]

19. Boengler, K.; Bulic, M.; Schreckenberg, R.; Schlüter, K.D.; Schulz, R. The gap junction modifier ZP1609 decreases cardiomyocyte hypercontracture following ischaemia/reperfusion independent from mitochondrial connexin 43. Br. J. Pharmacol. 2017, 174, 2060-2073. [CrossRef]

20. Johnstone, S.R.; Best, A.K.; Wright, C.S.; Isakson, B.E.; Errington, R.J.; Martin, P.E. Enhanced Connexin 43 Expression Delays Intra-Mitoitc Duration and Cell Cycle Traverse Independently of Gap Junction Channel Function. J. Cell. Biochem. 2010, 110, 772-782. [CrossRef]

21. Johnstone, S.R.; Kroncke, B.M.; Straub, A.C.; Best, A.K.; Dunn, C.A.; Mitchell, L.A.; Peskova, Y.; Nakamoto, R.K.; Koval, M.; Lo, C.W.; et al. MAPK Phosphorylation of Connexin 43 Promotes Binding of Cyclin E and Smooth Muscle Cell Proliferation. Circ. Res. 2012, 111, U201-U205. [CrossRef] [PubMed]

22. Obert, E.; Strauss, R.; Brandon, C.; Grek, C.; Ghatnekar, G.; Gourdie, R.; Rohrer, B. Targeting the tight junction protein, zonula occludens-1, with the connexin 43 mimetic peptide, alphaCT1, reduces VEGF-dependent RPE pathophysiology. J. Mol. Med. 2017, 95, 535-552. [CrossRef]

23. Rhett, J.M.; Calder, B.W.; Fann, S.A.; Bainbridge, H.; Gourdie, R.G.; Yost, M.J. Mechanism of action of the anti-inflammatory connexin 43 mimetic peptide JM2. Am. J. Physiol. Cell Physiol. 2017, 313, C314-C326. [CrossRef]

24. Rhett, J.M.; Ongstad, E.L.; Jourdan, J.; Gourdie, R.G. Cx43 associates with Na(v)1.5 in the cardiomyocyte perinexus. J. Membr. Biol. 2012, 245, 411-422. [CrossRef]

25. Barker, R.J.; Price, R.L.; Gourdie, R.G. Increased association of ZO-1 with connexin 43 during remodeling of cardiac gap junctions. Circ. Res. 2002, 90, 317-324. [CrossRef]

26. Calhoun, P.J.; Phan, A.V.; Taylor, J.D.; James, C.C.; Padget, R.L.; Zeitz, M.J.; Smyth, J.W. Adenovirus targets transcriptional and posttranslational mechanisms to limit gap junction function. FASEB J. 2020, 34, 9694-9712. [CrossRef]

27. James, C.C.; Zeitz, M.J.; Calhoun, P.J.; Lamouille, S.; Smyth, J.W. Altered translation initiation of Gja1 limits gap junction formation during epithelial-mesenchymal transition. Mol. Biol. Cell 2018, 29, 797-808. [CrossRef]

28. Smyth, J.W.; Zhang, S.S.; Sanchez, J.M.; Lamouille, S.; Vogan, J.M.; Hesketh, G.G.; Hong, T.; Tomaselli, G.F.; Shaw, R.M. A 14-3-3 mode-1 binding motif initiates gap junction internalization during acute cardiac ischemia. Traffic 2014, 15, 684-699. [CrossRef] 
29. Zeitz, M.J.; Calhoun, P.J.; James, C.C.; Taetzsch, T.; George, K.K.; Robel, S.; Valdez, G.; Smyth, J.W. Dynamic UTR Usage Regulates Alternative Translation to Modulate Gap Junction Formation during Stress and Aging. Cell Rep. 2019, 27, 2737-2747.e5. [CrossRef] [PubMed]

30. Smyth, J.W.; Shaw, R.M. Autoregulation of connexin 43 gap junction formation by internally translated isoforms. Cell Rep. 2013, 5, 611-618. [CrossRef]

31. Epifantseva, I.; Xiao, S.; Baum, R.E.; Kléber, A.G.; Hong, T.; Shaw, R.M. An Alternatively Translated Connexin 43 Isoform, GJA1-11k, Localizes to the Nucleus and Can Inhibit Cell Cycle Progression. Biomolecules 2020, 10, 473. [CrossRef] [PubMed]

32. Johnstone, S.R.; Billaud, M.; Lohman, A.W.; Taddeo, E.P.; Isakson, B.E. Posttranslational Modifications in Connexins and Pannexins. J. Membr. Biol. 2012, 245, 319-332. [CrossRef] [PubMed]

33. Aasen, T.; Johnstone, S.; Vidal-Brime, L.; Lynn, K.S.; Koval, M. Connexins: Synthesis, Post-Translational Modifications, and Trafficking in Health and Disease. Int. J. Mol. Sci. 2018, 19, 1296. [CrossRef] [PubMed]

34. Jacobsen, N.L.; Pontifex, T.K.; Li, H.; Solan, J.L.; Lampe, P.D.; Sorgen, P.L.; Burt, J.M. Regulation of Cx37 channel and growthsuppressive properties by phosphorylation. J. Cell Sci. 2017, 130, 3308-3321. [CrossRef]

35. Liu, J.; Ek Vitorin, J.F.; Weintraub, S.T.; Gu, S.; Shi, Q.; Burt, J.M.; Jiang, J.X. Phosphorylation of connexin 50 by protein kinase a enhances gap junction and hemichannel function. J. Biol. Chem. 2011, 286, 16914-16928. [CrossRef]

36. Lampe, P.D.; Cooper, C.D.; King, T.J.; Burt, J.M. Analysis of Connexin 43 phosphorylated at S325, S328 and S330 in normoxic and ischemic heart. J. Cell Sci. 2006, 119, 3435-3442. [CrossRef] [PubMed]

37. Cottrell, G.T.; Lin, R.; Warn-Cramer, B.J.; Lau, A.F.; Burt, J.M. Mechanism of v-Src- and mitogen-activated protein kinase-induced reduction of gap junction communication. Am. J. Physiol. Cell Physiol. 2003, 284, C511-C520. [CrossRef]

38. Solan, J.L.; Marquez-Rosado, L.; Sorgen, P.L.; Thornton, P.J.; Gafken, P.R.; Lampe, P.D. Phosphorylation at S365 is a gatekeeper event that changes the structure of Cx43 and prevents down-regulation by PKC. J. Cell Biol. 2007, 179, 1301-1309. [CrossRef]

39. Locke, D.; Bian, S.; Li, H.; Harris, A.L. Post-translational modifications of connexin 26 revealed by mass spectrometry. Biochem. J. 2009, 424, 385-398. [CrossRef]

40. Bouvier, D.; Kieken, F.; Kellezi, A.; Sorgen, P.L. Structural changes in the carboxyl terminus of the gap junction protein connexin40 caused by the interaction with c-Src and zonula occludens-1. Cell Commun. Adhes. 2008, 15, 107-118. [CrossRef]

41. Bouvier, D.; Spagnol, G.; Chenavas, S.; Kieken, F.; Vitrac, H.; Brownell, S.; Kellezi, A.; Forge, V.; Sorgen, P.L. Characterization of the structure and intermolecular interactions between the connexin 40 and connexin 43 carboxyl-terminal and cytoplasmic loop domains. J. Biol. Chem. 2009, 284, 34257-34271. [CrossRef] [PubMed]

42. Duffy, H.S.; Sorgen, P.L.; Girvin, M.E.; O’Donnell, P.; Coombs, W.; Taffet, S.M.; Delmar, M.; Spray, D.C. pH-dependent intramolecular binding and structure involving Cx43 cytoplasmic domains. J. Biol. Chem. 2002, 277, 36706-36714. [CrossRef] [PubMed]

43. Grosely, R.; Kieken, F.; Sorgen, P.L. ${ }^{1} \mathrm{H},{ }^{13} \mathrm{C}$, and ${ }^{15} \mathrm{~N}$ backbone resonance assignments of the connexin 43 carboxyl terminal domain attached to the 4th transmembrane domain in detergent micelles. Biomol. NMR Assign. 2013, 7, 299-303. [CrossRef]

44. Sorgen, P.L.; Duffy, H.S.; Cahill, S.M.; Coombs, W.; Spray, D.C.; Delmar, M.; Girvin, M.E. Sequence-specific resonance assignment of the carboxyl terminal domain of Connexin 43. J. Biomol. NMR 2002, 23, 245-246. [CrossRef] [PubMed]

45. Sorgen, P.L.; Duffy, H.S.; Spray, D.C.; Delmar, M. pH-dependent dimerization of the carboxyl terminal domain of Cx43. Biophys. J. 2004, 87, 574-581. [CrossRef]

46. Faniku, C.; O'Shaughnessy, E.; Lorraine, C.; Johnstone, S.R.; Graham, A.; Greenhough, S.; Martin, P.E.M. The Connexin Mimetic Peptide Gap27 and Cx43-Knockdown Reveal Differential Roles for Connexin 43 in Wound Closure Events in Skin Model Systems. Int. J. Mol. Sci. 2018, 19, 604. [CrossRef] [PubMed]

47. Greer, K.; Chen, J.; Brickler, T.; Gourdie, R.; Theus, M.H. Modulation of gap junction-associated Cx43 in neural stem/progenitor cells following traumatic brain injury. Brain Res. Bull. 2017, 134, 38-46. [CrossRef]

48. Montgomery, J.; Ghatnekar, G.S.; Grek, C.L.; Moyer, K.E.; Gourdie, R.G. Connexin 43-Based Therapeutics for Dermal Wound Healing. Int. J. Mol. Sci. 2018, 19, 1778. [CrossRef]

49. Palatinus, J.A.; Gourdie, R.G. Diabetes Increases Cryoinjury Size with Associated Effects on Cx43 Gap Junction Function and Phosphorylation in the Mouse Heart. J. Diabetes Res. 2016, 2016, 8789617. [CrossRef]

50. BEVAN, J.A.; SU, C. The Sympathetic Mechanism in the Isolated Pulmonary Artery of the Rabbit. Br. J. Pharmacol. Chemother. 1964, 22, 176-182. [CrossRef]

51. Dhein, S.; Larsen, B.D.; Petersen, J.S.; Mohr, F.W. Effects of the new antiarrhythmic peptide ZP123 on epicardial activation and repolarization pattern. Cell Commun. Adhes. 2003, 10, 371-378. [CrossRef]

52. Engstrøm, T.; Nepper-Christensen, L.; Helqvist, S.; Kløvgaard, L.; Holmvang, L.; Jørgensen, E.; Pedersen, F.; Saunamaki, K.; Tilsted, H.H.; Steensberg, A.; et al. Danegaptide for primary percutaneous coronary intervention in acute myocardial infarction patients: A phase 2 randomised clinical trial. Heart 2018, 104, 1593-1599. [CrossRef]

53. Grek, C.L.; Montgomery, J.; Sharma, M.; Ravi, A.; Rajkumar, J.S.; Moyer, K.E.; Gourdie, R.G.; Ghatnekar, G.S. A Multicenter Randomized Controlled Trial Evaluating a Cx43-Mimetic Peptide in Cutaneous Scarring. J. Invest. Dermatol. 2017, 137, 620-630. [CrossRef]

54. Evans, W.H.; Leybaert, L. Mimetic peptides as blockers of connexin channel-facilitated intercellular communication. Cell Commun. Adhes. 2007, 14, 265-273. [CrossRef] 
55. Leybaert, L.; Lampe, P.D.; Dhein, S.; Kwak, B.R.; Ferdinandy, P.; Beyer, E.C.; Laird, D.W.; Naus, C.C.; Green, C.R.; Schulz, R. Connexins in Cardiovascular and Neurovascular Health and Disease: Pharmacological Implications. Pharmacol. Rev. 2017, 69, 396-478. [CrossRef]

56. Schulz, R.; Görge, P.M.; Görbe, A.; Ferdinandy, P.; Lampe, P.D.; Leybaert, L. Connexin 43 is an emerging therapeutic target in ischemia/reperfusion injury, cardioprotection and neuroprotection. Pharmacol. Ther. 2015, 153, 90-106. [CrossRef]

57. Giaume, C.; Leybaert, L.; Naus, C.C.; Saez, J.C. Connexin and pannexin hemichannels in brain glial cells: Properties, pharmacology, and roles. Front. Pharmacol. 2013, 4, 88. [CrossRef] [PubMed]

58. De Vuyst, E.; Boengler, K.; Antoons, G.; Sipido, K.R.; Schulz, R.; Leybaert, L. Pharmacological modulation of connexin-formed channels in cardiac pathophysiology. Br. J. Pharmacol. 2011, 163, 469-483. [CrossRef] [PubMed]

59. Marsh, S.R.; Williams, Z.J.; Pridham, K.J.; Gourdie, R.G. Peptidic Connexin 43 Therapeutics in Cardiac Reparative Medicine. J. Cardiovasc Dev. Dis. 2021, 8, 52. [CrossRef]

60. Green, C.R.; Severs, N.J. Gap junction connexon configuration in rapidly frozen myocardium and isolated intercalated disks. J. Cell Biol. 1984, 99, 453-463. [CrossRef] [PubMed]

61. Dunn, C.A.; Lampe, P.D. Injury-triggered Akt phosphorylation of Cx43: A ZO-1-driven molecular switch that regulates gap junction size. J. Cell Sci. 2014, 127, 455-464. [CrossRef] [PubMed]

62. Jeyaraman, M.M.; Srisakuldee, W.; Nickel, B.E.; Kardami, E. Connexin 43 phosphorylation and cytoprotection in the heart. Biochim. Biophys. Acta 2012, 1818, 2009-2013. [CrossRef]

63. George, S.A.; Hoeker, G.; Calhoun, P.J.; Entz, M., 2nd; Raisch, T.B.; King, D.R.; Khan, M.; Baker, C.; Gourdie, R.G.; Smyth, J.W.; et al. Modulating cardiac conduction during metabolic ischemia with perfusate sodium and calcium in guinea pig hearts. Am. $J$. Physiol. Heart Circ. Physiol. 2019, 316, H849-H861. [CrossRef] [PubMed]

64. Aonuma, S.; Kohama, Y.; Akai, K.; Komiyama, Y.; Nakajima, S.; Wakabayashi, M.; Makino, T. Studies on heart. XIX. Isolation of an atrial peptide that improves the rhythmicity of cultured myocardial cell clusters. Chem. Pharm. Bull. 1980, 28, 3332-3339. [CrossRef]

65. Jozwiak, J.; Dhein, S. Local effects and mechanisms of antiarrhythmic peptide AAP10 in acute regional myocardial ischemia: Electrophysiological and molecular findings. Naunyn Schmiedebergs Arch Pharmacol. 2008, 378, 459-470. [CrossRef] [PubMed]

66. Quan, X.Q.; Bai, R.; Liu, N.; Chen, B.D.; Zhang, C.T. Increasing gap junction coupling reduces transmural dispersion of repolarization and prevents torsade de pointes in rabbit LQT3 model. J. Cardiovasc. Electrophysiol. 2007, 18, 1184-1189. [CrossRef]

67. Quan, X.Q.; Bai, R.; Lu, J.G.; Patel, C.; Liu, N.; Ruan, Y.; Chen, B.D.; Ruan, L.; Zhang, C.T. Pharmacological enhancement of cardiac gap junction coupling prevents arrhythmias in canine LQT2 model. Cell Commun. Adhes. 2009, 16, 29-38. [CrossRef]

68. Axelsen, L.N.; Stahlhut, M.; Mohammed, S.; Larsen, B.D.; Nielsen, M.S.; Holstein-Rathlou, N.H.; Andersen, S.; Jensen, O.N.; Hennan, J.K.; Kjolbye, A.L. Identification of ischemia-regulated phosphorylation sites in connexin 43: A possible target for the antiarrhythmic peptide analogue rotigaptide (ZP123). J. Mol. Cell. Cardiol. 2006, 40, 790-798. [CrossRef]

69. Skyschally, A.; Walter, B.; Schultz Hansen, R.; Heusch, G. The antiarrhythmic dipeptide ZP1609 (danegaptide) when given at reperfusion reduces myocardial infarct size in pigs. Naunyn Schmiedebergs Arch Pharmacol. 2013, 386, 383-391. [CrossRef]

70. Hennan, J.K.; Swillo, R.E.; Morgan, G.A.; Keith, J.C.; Schaub, R.G.; Smith, R.P.; Feldman, H.S.; Haugan, K.; Kantrowitz, J.; Wang, P.J.; et al. Rotigaptide (ZP123) prevents spontaneous ventricular arrhythmias and reduces infarct size during myocardial ischemia/reperfusion injury in open-chest dogs. J. Pharmacol. Exp. Ther. 2006, 317, 236-243. [CrossRef] [PubMed]

71. Johnstone, S.R.; Isakson, B.E. 'Gaps' in targeted ischaemic injury therapies in ST-elevation myocardial infarction. Heart 2018, 104, 1557-1558. [CrossRef] [PubMed]

72. Easton, J.A.; Petersen, J.S.; Martin, P.E. The anti-arrhythmic peptide AAP10 remodels Cx43 and Cx40 expression and function. Naunyn Schmiedebergs Arch. Pharmacol. 2009, 380, 11-24. [CrossRef]

73. Clarke, T.C.; Williams, O.J.; Martin, P.E.; Evans, W.H. ATP release by cardiac myocytes in a simulated ischaemia model: Inhibition by a connexin mimetic and enhancement by an antiarrhythmic peptide. Eur. J. Pharmacol. 2009, 605, 9-14. [CrossRef] [PubMed]

74. Patin, J.; Castro, C.; Steenman, M.; Hivonnait, A.; Carcouët, A.; Tessier, A.; Lebreton, J.; Bihouée, A.; Donnart, A.; Le Marec, H.; et al. Gap-134, a Connexin 43 activator, prevents age-related development of ventricular fibrosis in Scn5a. Pharmacol. Res. 2020, 159, 104922. [CrossRef] [PubMed]

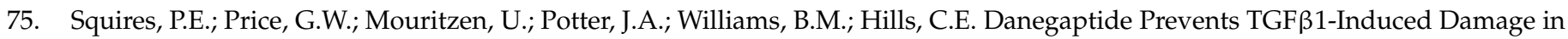
Human Proximal Tubule Epithelial Cells of the Kidney. Int. J. Mol. Sci. 2021, 22, 2809. [CrossRef]

76. Weng, S.; Lauven, M.; Schaefer, T.; Polontchouk, L.; Grover, R.; Dhein, S. Pharmacological modification of gap junction coupling by an antiarrhythmic peptide via protein kinase C activation. FASEB J. 2002, 16, 1114-1116. [CrossRef]

77. Dhein, S.; Weng, S.; Grover, R.; Tudyka, T.; Gottwald, M.; Schaefer, T.; Polontchouk, L. Protein kinase Calpha mediates the effect of antiarrhythmic peptide on gap junction conductance. Cell Commun. Adhes. 2001, 8, 257-264. [CrossRef]

78. Stahlhut, M.; Petersen, J.S.; Hennan, J.K.; Ramirez, M.T. The antiarrhythmic peptide rotigaptide (ZP123) increases connexin 43 protein expression in neonatal rat ventricular cardiomyocytes. Cell Commun. Adhes. 2006, 13, 21-27. [CrossRef]

79. Haugan, K.; Kjølbye, A.L.; Hennan, J.K.; Petersen, J.S. Rotigaptide (ZP123) reverts established atrial conduction velocity slowing. Cell Commun. Adhes. 2005, 12, 271-278. [CrossRef] [PubMed]

80. Xue, J.; Yan, X.; Yang, Y.; Chen, M.; Wu, L.; Gou, Z.; Sun, Z.; Talabieke, S.; Zheng, Y.; Luo, D. Connexin 43 dephosphorylation contributes to arrhythmias and cardiomyocyte apoptosis in ischemia/reperfusion hearts. Basic Res. Cardiol. 2019, 114, 40. [CrossRef] [PubMed] 
81. Alstrom, J.S.; Stroemlund, L.W.; Nielsen, M.S.; MacAulay, N. Protein kinase C-dependent regulation of connexin 43 gap junctions and hemichannels. Biochem. Soc. Trans. 2015, 43, 519-523. [CrossRef]

82. Doble, B.W.; Dang, X.; Ping, P.; Fandrich, R.R.; Nickel, B.E.; Jin, Y.; Cattini, P.A.; Kardami, E. Phosphorylation of serine 262 in the gap junction protein connexin-43 regulates DNA synthesis in cell-cell contact forming cardiomyocytes. J. Cell Sci. 2004, 117, 507-514. [CrossRef]

83. Doble, B.W.; Ping, P.; Kardami, E. The epsilon subtype of protein kinase C is required for cardiomyocyte connexin-43 phosphorylation. Circ. Res. 2000, 86, 293-301. [CrossRef] [PubMed]

84. Grover, R.; Dhein, S. Structure-activity relationships of novel peptides related to the antiarrhythmic peptide AAP10 which reduce the dispersion of epicardial action potential duration. Peptides 2001, 22, 1011-1021. [CrossRef]

85. Aasen, T.; Mesnil, M.; Naus, C.C.; Lampe, P.D.; Laird, D.W. Gap junctions and cancer: Communicating for 50 years. Nat. Rev. Cancer 2017, 17, 74. [CrossRef]

86. Kim, D.; Mouritzen, U.; Larsen, B.D.; Roy, S. Inhibition of Cx43 gap junction uncoupling prevents high glucose-induced apoptosis and reduces excess cell monolayer permeability in retinal vascular endothelial cells. Exp. Eye Res. 2018, 173, 85-90. [CrossRef] [PubMed]

87. Freitas-Andrade, M.; Bechberger, J.; Wang, J.; Yeung, K.K.C.; Whitehead, S.N.; Hansen, R.S.; Naus, C.C. Danegaptide Enhances Astrocyte Gap Junctional Coupling and Reduces Ischemic Reperfusion Brain Injury in Mice. Biomolecules 2020, 10, 353. [CrossRef] [PubMed]

88. DeLalio, L.J.; Isakson, B.E. ZP1609/danegaptide and mitochondrial connexin hemichannels: A harbinger for peptide drug design. Br. J. Pharmacol. 2017, 174, 2606-2607. [CrossRef] [PubMed]

89. Yu, J.; Lin, Y.H.; Yang, L.; Huang, C.C.; Chen, L.; Wang, W.C.; Chen, G.W.; Yan, J.; Sawettanun, S.; Lin, C.H. Improved Anticancer Photothermal Therapy Using the Bystander Effect Enhanced by Antiarrhythmic Peptide Conjugated Dopamine-Modified Reduced Graphene Oxide Nanocomposite. Adv. Healthc Mater. 2017, 6. [CrossRef]

90. Yang, W.; Lampe, P.D.; Kensel-Hammes, P.; Hesson, J.; Ware, C.B.; Crisa, L.; Cirulli, V. Connexin 43 Functions as a Positive Regulator of Stem Cell Differentiation into Definitive Endoderm and Pancreatic Progenitors. iScience 2019, 19, 450-460. [CrossRef]

91. Chen, K.; Chen, L.; Ouyang, Y.; Zhang, L.; Li, X.; Li, L.; Si, J.; Wang, L.; Ma, K. Pirfenidone attenuates homocysteine-induced apoptosis by regulating the connexin 43 pathway in H9C2 cells. Int. J. Mol. Med. 2020, 45, 1081-1090. [CrossRef] [PubMed]

92. Chaytor, A.T.; Evans, W.H.; Griffith, T.M. Peptides homologous to extracellular loop motifs of connexin 43 reversibly abolish rhythmic contractile activity in rabbit arteries. J. Physiol. 1997, 503 Pt 1, 99-110. [CrossRef]

93. Chaytor, A.T.; Martin, P.E.; Evans, W.H.; Randall, M.D.; Griffith, T.M. The endothelial component of cannabinoid-induced relaxation in rabbit mesenteric artery depends on gap junctional communication. J. Physiol. 1999, 520 Pt 2, 539-550. [CrossRef]

94. Chaytor, A.T.; Martin, P.E.; Edwards, D.H.; Griffith, T.M. Gap junctional communication underpins EDHF-type relaxations evoked by ACh in the rat hepatic artery. Am. J. Physiol. Heart Circ. Physiol. 2001, 280, H2441-H2450. [CrossRef] [PubMed]

95. Ju, H.; Wang, Y.; Shi, Q.; Zhou, Y.; Ma, R.; Wu, P.; Fang, H. Inhibition of connexin 43 hemichannels improves postoperative cognitive function in aged mice. Am. J. Transl. Res. 2019, 11, 2280-2287.

96. Wright, C.S.; van Steensel, M.A.; Hodgins, M.B.; Martin, P.E. Connexin mimetic peptides improve cell migration rates of human epidermal keratinocytes and dermal fibroblasts in vitro. Wound Repair Regen. 2009, 17, 240-249. [CrossRef]

97. Eugenín, E.A.; González, H.; Sáez, C.G.; Sáez, J.C. Gap junctional communication coordinates vasopressin-induced glycogenolysis in rat hepatocytes. Am. J. Physiol. 1998, 274, G1109-G1116. [CrossRef] [PubMed]

98. Mendoza-Naranjo, A.; Saéz, P.J.; Johansson, C.C.; Ramírez, M.; Mandakovic, D.; Pereda, C.; López, M.N.; Kiessling, R.; Sáez, J.C.; Salazar-Onfray, F. Functional gap junctions facilitate melanoma antigen transfer and cross-presentation between human dendritic cells. J. Immunol. 2007, 178, 6949-6957. [CrossRef]

99. Kwak, B.R.; Jongsma, H.J. Selective inhibition of gap junction channel activity by synthetic peptides. J. Physiol. 1999, 516 Pt 3, 679-685. [CrossRef]

100. Martin, P.E.; Wall, C.; Griffith, T.M. Effects of connexin-mimetic peptides on gap junction functionality and connexin expression in cultured vascular cells. Br. J. Pharmacol. 2005, 144, 617-627. [CrossRef]

101. De Bock, M.; Wang, N.; Bol, M.; Decrock, E.; Ponsaerts, R.; Bultynck, G.; Dupont, G.; Leybaert, L. Connexin 43 hemichannels contribute to cytoplasmic $\mathrm{Ca}^{2+}$ oscillations by providing a bimodal $\mathrm{Ca}^{2+}$-dependent $\mathrm{Ca}^{2+}$ entry pathway. J. Biol. Chem. 2012, 287, 12250-12266. [CrossRef]

102. Sahli, K.A.; Flora, G.D.; Sasikumar, P.; Maghrabi, A.H.; Holbrook, L.M.; AlOuda, S.K.; Elgheznawy, A.; Sage, T.; Stainer, A.R.; Adiyaman, R.; et al. Structural, functional, and mechanistic insights uncover the fundamental role of orphan connexin-62 in platelets. Blood 2021, 137, 830-843. [CrossRef] [PubMed]

103. O'Carroll, S.J.; Alkadhi, M.; Nicholson, L.F.; Green, C.R. Connexin 43 mimetic peptides reduce swelling, astrogliosis, and neuronal cell death after spinal cord injury. Cell Commun. Adhes. 2008, 15, 27-42. [CrossRef] [PubMed]

104. Danesh-Meyer, H.V.; Kerr, N.M.; Zhang, J.; Eady, E.K.; O'Carroll, S.J.; Nicholson, L.F.; Johnson, C.S.; Green, C.R. Connexin 43 mimetic peptide reduces vascular leak and retinal ganglion cell death following retinal ischaemia. Brain 2012, 135, 506-520. [CrossRef]

105. Mao, Y.; Nguyen, T.; Tonkin, R.S.; Lees, J.G.; Warren, C.; O’Carroll, S.J.; Nicholson, L.F.B.; Green, C.R.; Moalem-Taylor, G.; Gorrie, C.A. Characterisation of Peptide5 systemic administration for treating traumatic spinal cord injured rats. Exp. Brain Res. 2017, 235, 3033-3048. [CrossRef] 
106. Mao, Y.; Tonkin, R.S.; Nguyen, T.; O'Carroll, S.J.; Nicholson, L.F.; Green, C.R.; Moalem-Taylor, G.; Gorrie, C.A. Systemic Administration of Connexin 43 Mimetic Peptide Improves Functional Recovery after Traumatic Spinal Cord Injury in Adult Rats. J. Neurotrauma 2017, 34, 707-719. [CrossRef]

107. Cotter, M.L.; Boitano, S.; Lampe, P.D.; Solan, J.L.; Vagner, J.; Ek-Vitorin, J.F.; Burt, J.M. The lipidated connexin mimetic peptide SRPTEKT-. Am. J. Physiol. Cell Physiol. 2019, 317, C825-C842. [CrossRef] [PubMed]

108. Cotter, M.L.; Boitano, S.; Vagner, J.; Burt, J.M. Lipidated connexin mimetic peptides potently inhibit gap junction-mediated Ca. Am. J. Physiol. Cell Physiol. 2018, 315, C141-C154. [CrossRef] [PubMed]

109. Chen, Y.S.; Toth, I.; Danesh-Meyer, H.V.; Green, C.R.; Rupenthal, I.D. Cytotoxicity and vitreous stability of chemically modified connexin 43 mimetic peptides for the treatment of optic neuropathy. J. Pharm. Sci. 2013, 102, 2322-2331. [CrossRef] [PubMed]

110. De Vuyst, E.; Decrock, E.; Cabooter, L.; Dubyak, G.R.; Naus, C.C.; Evans, W.H.; Leybaert, L. Intracellular calcium changes trigger connexin 32 hemichannel opening. EMBO J. 2006, 25, 34-44. [CrossRef]

111. Maes, M.; Crespo Yanguas, S.; Willebrords, J.; Weemhoff, J.L.; da Silva, T.C.; Decrock, E.; Lebofsky, M.; Pereira, I.V.A.; Leybaert, L.; Farhood, A.; et al. Connexin hemichannel inhibition reduces acetaminophen-induced liver injury in mice. Toxicol Lett. 2017, 278, 30-37. [CrossRef] [PubMed]

112. Seki, A.; Duffy, H.S.; Coombs, W.; Spray, D.C.; Taffet, S.M.; Delmar, M. Modifications in the biophysical properties of connexin 43 channels by a peptide of the cytoplasmic loop region. Circ. Res. 2004, 95, e22-e28. [CrossRef] [PubMed]

113. Seki, A.; Coombs, W.; Taffet, S.M.; Delmar, M. Loss of electrical communication, but not plaque formation, after mutations in the cytoplasmic loop of connexin 43. Heart Rhythm 2004, 1, 227-233. [CrossRef]

114. Ponsaerts, R.; De Vuyst, E.; Retamal, M.; D’Hondt, C.; Vermeire, D.; Wang, N.; De Smedt, H.; Zimmermann, P.; Himpens, B.; Vereecke, J.; et al. Intramolecular loop/tail interactions are essential for connexin 43-hemichannel activity. FASEB J. 2010, 24, 4378-4395. [CrossRef] [PubMed]

115. Wang, N.; De Vuyst, E.; Ponsaerts, R.; Boengler, K.; Palacios-Prado, N.; Wauman, J.; Lai, C.P.; De Bock, M.; Decrock, E.; Bol, M.; et al. Selective inhibition of Cx43 hemichannels by Gap19 and its impact on myocardial ischemia/reperfusion injury. Basic Res. Cardiol. 2013, 108, 309. [CrossRef]

116. Becker, D.L.; Evans, W.H.; Green, C.R.; Warner, A. Functional analysis of amino acid sequences in connexin 43 involved in intercellular communication through gap junctions. J. Cell Sci. 1995, 108 Pt 4, 1455-1467. [CrossRef]

117. Abudara, V.; Bechberger, J.; Freitas-Andrade, M.; De Bock, M.; Wang, N.; Bultynck, G.; Naus, C.C.; Leybaert, L.; Giaume, C. The connexin 43 mimetic peptide Gap19 inhibits hemichannels without altering gap junctional communication in astrocytes. Front. Cell Neurosci. 2014, 8, 306. [CrossRef] [PubMed]

118. Coutinho, F.P.; Green, C.R.; Acosta, M.L.; Rupenthal, I.D. Xentry-Gap19 inhibits Connexin 43 hemichannel opening especially during hypoxic injury. Drug Deliv. Transl. Res. 2020, 10, 751-765. [CrossRef] [PubMed]

119. Earley, S.; Resta, T.C.; Walker, B.R. Disruption of smooth muscle gap junctions attenuates myogenic vasoconstriction of mesenteric resistance arteries. Am. J. Physiol. Heart Circ. Physiol. 2004, 287, H2677-H2686. [CrossRef]

120. Palatinus, J.A.; Rhett, J.M.; Gourdie, R.G. Enhanced PKCepsilon mediated phosphorylation of connexin 43 at serine 368 by a carboxyl-terminal mimetic peptide is dependent on injury. Channels 2011, 5, 236-240. [CrossRef]

121. Hunter, A.W.; Barker, R.J.; Zhu, C.; Gourdie, R.G. Zonula occludens-1 alters connexin 43 gap junction size and organization by influencing channel accretion. Mol. Biol. Cell 2005, 16, 5686-5698. [CrossRef]

122. Ghatnekar, G.S.; O'Quinn, M.P.; Jourdan, L.J.; Gurjarpadhye, A.A.; Draughn, R.L.; Gourdie, R.G. Connexin 43 carboxyl-terminal peptides reduce scar progenitor and promote regenerative healing following skin wounding. Regen. Med. 2009, 4, 205-223. [CrossRef] [PubMed]

123. Jiang, J.; Hoagland, D.; Palatinus, J.A.; He, H.; Iyyathurai, J.; Jourdan, L.J.; Bultynck, G.; Wang, Z.; Zhang, Z.; Schey, K.; et al. Interaction of alpha Carboxyl Terminus 1 Peptide with the Connexin 43 Carboxyl Terminus Preserves Left Ventricular Function After Ischemia-Reperfusion Injury. J. Am. Heart Assoc. 2019, 8, e012385. [CrossRef] [PubMed]

124. Bond, S.R.; Wang, N.; Leybaert, L.; Naus, C.C. Pannexin 1 ohnologs in the teleost lineage. J. Membr. Biol. 2012, $245,483-493$. [CrossRef]

125. O'Quinn, M.P.; Palatinus, J.A.; Harris, B.S.; Hewett, K.W.; Gourdie, R.G. A peptide mimetic of the connexin 43 carboxyl terminus reduces gap junction remodeling and induced arrhythmia following ventricular injury. Circ. Res. 2011, 108, 704-715. [CrossRef] [PubMed]

126. Verma, V.; Larsen, B.D.; Coombs, W.; Lin, X.; Sarrou, E.; Taffet, S.M.; Delmar, M. Design and characterization of the first peptidomimetic molecule that prevents acidification-induced closure of cardiac gap junctions. Heart Rhythm 2010, 7, 1491-1498. [CrossRef] [PubMed]

127. Calder, B.W.; Matthew Rhett, J.; Bainbridge, H.; Fann, S.A.; Gourdie, R.G.; Yost, M.J. Inhibition of connexin 43 hemichannelmediated ATP release attenuates early inflammation during the foreign body response. Tissue Eng. Part. A 2015, 21, 1752-1762. [CrossRef]

128. Pelaz, S.G.; Jaraíz-Rodríguez, M.; Álvarez-Vázquez, A.; Talaverón, R.; García-Vicente, L.; Flores-Hernández, R.; Gómez de Cedrón, M.; Tabernero, M.; Ramírez de Molina, A.; Lillo, C.; et al. Targeting metabolic plasticity in glioma stem cells in vitro and in vivo through specific inhibition of c-Src by TAT-Cx43. EBioMedicine 2020, 62, 103134. [CrossRef] [PubMed] 
129. Talaveron, R.; Matarredona, E.R.; Herrera, A.; Medina, J.M.; Tabernero, A. Connexin 43 Region 266-283, via Src Inhibition, Reduces Neural Progenitor Cell Proliferation Promoted by EGF and FGF-2 and Increases Astrocytic Differentiation. Int. J. Mol. Sci. 2020, 21, 8852. [CrossRef]

130. Meyer, R.A.; Laird, D.W.; Revel, J.P.; Johnson, R.G. Inhibition of gap junction and adherens junction assembly by connexin and A-CAM antibodies. J. Cell Biol. 1992, 119, 179-189. [CrossRef]

131. Goodenough, D.A.; Paul, D.L.; Jesaitis, L. Topological distribution of two connexin 32 antigenic sites in intact and split rodent hepatocyte gap junctions. J. Cell Biol. 1988, 107, 1817-1824. [CrossRef] [PubMed]

132. Dahl, G.; Nonner, W.; Werner, R. Attempts to define functional domains of gap junction proteins with synthetic peptides. Biophys. J. 1994, 67, 1816-1822. [CrossRef]

133. Evans, W.H.; Boitano, S. Connexin mimetic peptides: Specific inhibitors of gap-junctional intercellular communication. Biochem.Soc. Trans. 2001, 29, 606-612. [CrossRef]

134. Warner, A.; Clements, D.K.; Parikh, S.; Evans, W.H.; DeHaan, R.L. Specific motifs in the external loops of connexin proteins can determine gap junction formation between chick heart myocytes. J. Physiol. 1995, 488 Pt 3, 721-728. [CrossRef] [PubMed]

135. Glass, B.J.; Hu, R.G.; Phillips, A.R.; Becker, D.L. The action of mimetic peptides on connexins protects fibroblasts from the negative effects of ischemia reperfusion. Biol. Open 2015, 4, 1473-1480. [CrossRef]

136. Desplantez, T.; Verma, V.; Leybaert, L.; Evans, W.H.; Weingart, R. Gap26, a connexin mimetic peptide, inhibits currents carried by connexin 43 hemichannels and gap junction channels. Pharmacol. Res. 2012, 65, 546-552. [CrossRef]

137. Davidson, J.O.; Green, C.R.; Nicholson, L.F.; O'Carroll, S.J.; Fraser, M.; Bennet, L.; Gunn, A.J. Connexin hemichannel blockade improves outcomes in a model of fetal ischemia. Ann. Neurol. 2012, 71, 121-132. [CrossRef]

138. Wang, N.; De Bock, M.; Decrock, E.; Bol, M.; Gadicherla, A.; Bultynck, G.; Leybaert, L. Connexin targeting peptides as inhibitors of voltage- and intracellular $\mathrm{Ca}^{2+}$-triggered Cx43 hemichannel opening. Neuropharmacology 2013, 75, 506-516. [CrossRef]

139. Berman, R.S.; Martin, P.E.; Evans, W.H.; Griffith, T.M. Relative contributions of NO and gap junctional communication to endothelium-dependent relaxations of rabbit resistance arteries vary with vessel size. Microvasc Res. 2002, 63, 115-128. [CrossRef]

140. Elbadawy, H.M.; Mirabelli, P.; Xeroudaki, M.; Parekh, M.; Bertolin, M.; Breda, C.; Cagini, C.; Ponzin, D.; Lagali, N.; Ferrari, S. Effect of connexin 43 inhibition by the mimetic peptide Gap27 on corneal wound healing, inflammation and neovascularization. Br. J. Pharmacol. 2016, 173, 2880-2893. [CrossRef]

141. Wright, C.S.; Pollok, S.; Flint, D.J.; Brandner, J.M.; Martin, P.E. The connexin mimetic peptide Gap27 increases human dermal fibroblast migration in hyperglycemic and hyperinsulinemic conditions in vitro. J. Cell Physiol. 2012, 227, 77-87. [CrossRef] [PubMed]

142. Hawat, G.; Hélie, P.; Baroudi, G. Single intravenous low-dose injections of connexin 43 mimetic peptides protect ischemic heart in vivo against myocardial infarction. J. Mol. Cell. Cardiol. 2012, 53, 559-566. [CrossRef] [PubMed]

143. Sorensen, C.M.; Salomonsson, M.; Braunstein, T.H.; Nielsen, M.S.; Holstein-Rathlou, N.H. Connexin mimetic peptides fail to inhibit vascular conducted calcium responses in renal arterioles. Am. J. Physiol. Regul Integr. Comp. Physiol. 2008, 295, R840-R847. [CrossRef] [PubMed]

144. Matchkov, V.V.; Rahman, A.; Bakker, L.M.; Griffith, T.M.; Nilsson, H.; Aalkjaer, C. Analysis of effects of connexin-mimetic peptides in rat mesenteric small arteries. Am. J. Physiol. Heart Circ. Physiol. 2006, 291, H357-H367. [CrossRef] [PubMed]

145. Solan, J.L.; Lampe, P.D. Connexin phosphorylation as a regulatory event linked to gap junction channel assembly. Biochim. Biophys. Acta 2005, 1711, 154-163. [CrossRef]

146. Solan, J.L.; Lampe, P.D. Connexin 43 phosphorylation: Structural changes and biological effects. Biochem. J. 2009, 419, $261-272$. [CrossRef]

147. Simon, A.; Magyar, C.; Heja, L.; Kardon, J. Peptide binding sites of connexin proteins. Chemistry 2020, 2, 662-673. [CrossRef]

148. Neijssen, J.; Herberts, C.; Drijfhout, J.W.; Reits, E.; Janssen, L.; Neefjes, J. Cross-presentation by intercellular peptide transfer through gap junctions. Nature 2005, 434, 83-88. [CrossRef] [PubMed]

149. Morley, G.E.; Taffet, S.M.; Delmar, M. Intramolecular interactions mediate pH regulation of connexin 43 channels. Biophys. J. 1996, 70, 1294-1302. [CrossRef]

150. Liu, S.; Taffet, S.; Stoner, L.; Delmar, M.; Vallano, M.L.; Jalife, J. A structural basis for the unequal sensitivity of the major cardiac and liver gap junctions to intracellular acidification: The carboxyl tail length. Biophys. J. 1993, 64, 1422-1433. [CrossRef]

151. Moreno, A.P.; Chanson, M.; Elenes, S.; Anumonwo, J.; Scerri, I.; Gu, H.; Taffet, S.M.; Delmar, M. Role of the carboxyl terminal of connexin 43 in transjunctional fast voltage gating. Circ. Res. 2002, 90, 450-457. [CrossRef] [PubMed]

152. Anumonwo, J.M.; Taffet, S.M.; Gu, H.; Chanson, M.; Moreno, A.P.; Delmar, M. The carboxyl terminal domain regulates the unitary conductance and voltage dependence of connexin40 gap junction channels. Circ. Res. 2001, 88, 666-673. [CrossRef] [PubMed]

153. D’hondt, C.; Iyyathurai, J.; Wang, N.; Gourdie, R.G.; Himpens, B.; Leybaert, L.; Bultynck, G. Negatively charged residues (Asp378 and Asp379) in the last ten amino acids of the C-terminal tail of $\mathrm{Cx} 43$ hemichannels are essential for loop/tail interactions. Biochem. Biophys. Res. Commun. 2013, 432, 707-712. [CrossRef] [PubMed]

154. Delmar, M.; Coombs, W.; Sorgen, P.; Duffy, H.S.; Taffet, S.M. Structural bases for the chemical regulation of Connexin 43 channels. Cardiovasc. Res. 2004, 62, 268-275. [CrossRef]

155. Gump, J.M.; Dowdy, S.F. TAT transduction: The molecular mechanism and therapeutic prospects. Trends Mol. Med. 2007, 13, 443-448. [CrossRef] 
156. Lindgren, M.; Hällbrink, M.; Prochiantz, A.; Langel, U. Cell-penetrating peptides. Trends Pharmacol. Sci. 2000, 21, 99-103. [CrossRef]

157. Carrigan, C.N.; Imperiali, B. The engineering of membrane-permeable peptides. Anal. Biochem. 2005, 341, 290-298. [CrossRef]

158. Yu, H.; Cao, X.; Li, W.; Liu, P.; Zhao, Y.; Song, L.; Chen, J.; Chen, B.; Yu, W.; Xu, Y. Targeting connexin 43 provides anti-inflammatory effects after intracerebral hemorrhage injury by regulating YAP signaling. J. Neuroinflamm. 2020, 17, 322. [CrossRef]

159. De Smet, M.A.; Lissoni, A.; Nezlobinsky, T.; Wang, N.; Dries, E.; Pérez-Hernández, M.; Lin, X.; Amoni, M.; Vervliet, T.; Witschas, K.; et al. Cx43 hemichannel microdomain signaling at the intercalated disc enhances cardiac excitability. J. Clin. Invest. 2021, 131. [CrossRef]

160. Deschenes, S.M.; Walcott, J.L.; Wexler, T.L.; Scherer, S.S.; Fischbeck, K.H. Altered trafficking of mutant connexin 32. J. Neurosci. 1997, 17, 9077-9084. [CrossRef]

161. Ressot, C.; Gomes, D.; Dautigny, A.; Pham-Dinh, D.; Bruzzone, R. Connexin 32 mutations associated with X-linked CharcotMarie-Tooth disease show two distinct behaviors: Loss of function and altered gating properties. J. Neurosci. 1998, 18, 4063-4075. [CrossRef] [PubMed]

162. Leithe, E.; Mesnil, M.; Aasen, T. The connexin 43 C-terminus: A tail of many tales. Biochim. Biophys. Acta Biomembr. 2018, 1860, 48-64. [CrossRef] [PubMed]

163. Rhett, J.M.; Jourdan, J.; Gourdie, R.G. Connexin 43 connexon to gap junction transition is regulated by zonula occludens-1. Mol. Biol. Cell 2011, 22, 1516-1528. [CrossRef] [PubMed]

164. Thevenin, A.F.; Margraf, R.A.; Fisher, C.G.; Kells-Andrews, R.M.; Falk, M.M. Phosphorylation regulates connexin 43/ZO-1 binding and release, an important step in gap junction turnover. Mol. Biol. Cell 2017, 28, 3595-3608. [CrossRef] [PubMed]

165. Lauf, U.; Giepmans, B.N.; Lopez, P.; Braconnot, S.; Chen, S.C.; Falk, M.M. Dynamic trafficking and delivery of connexons to the plasma membrane and accretion to gap junctions in living cells. Proc. Natl. Acad. Sci. USA 2002, 99, 10446-10451. [CrossRef] [PubMed]

166. Grek, C.L.; Prasad, G.M.; Viswanathan, V.; Armstrong, D.G.; Gourdie, R.G.; Ghatnekar, G.S. Topical administration of a connexin 43-based peptide augments healing of chronic neuropathic diabetic foot ulcers: A multicenter, randomized trial. Wound Repair Regen. 2015, 23, 203-212. [CrossRef]

167. Mugisho, O.O.; Green, C.R.; Zhang, J.; Acosta, M.L.; Rupenthal, I.D. Connexin 43 hemichannels: A potential drug target for the treatment of diabetic retinopathy. Drug Discov. Today 2019, 24, 1627-1636. [CrossRef]

168. Ghatnekar, G.S.; Grek, C.L.; Armstrong, D.G.; Desai, S.C.; Gourdie, R.G. The effect of a connexin 43-based Peptide on the healing of chronic venous leg ulcers: A multicenter, randomized trial. J. Invest. Dermatol. 2015, 135, 289-298. [CrossRef]

169. Grek, C.L.; Rhett, J.M.; Bruce, J.S.; Abt, M.A.; Ghatnekar, G.S.; Yeh, E.S. Targeting connexin 43 with alpha-connexin carboxylterminal (ACT1) peptide enhances the activity of the targeted inhibitors, tamoxifen and lapatinib, in breast cancer: Clinical implication for ACT1. BMC Cancer 2015, 15, 296. [CrossRef]

170. Montgomery, J.; Richardson, W.J.; Marsh, S.; Rhett, J.M.; Bustos, F.; Degen, K.; Ghatnekar, G.S.; Grek, C.L.; Jourdan, L.J.; Holmes, J.W.; et al. The connexin 43 carboxyl terminal mimetic peptide alphaCT1 prompts differentiation of a collagen scar matrix in humans resembling unwounded skin. FASEB J. 2021, 35, e21762. [CrossRef]

171. Strauss, R.E.; Mezache, L.; Veeraraghavan, R.; Gourdie, R.G. The Cx43 carboxyl-terminal mimetic peptide $\alpha$ CT1 protects endothelial barrier function in a ZO1 binding-competent manner. Biomolecules 2021, 11, 1192. [CrossRef] [PubMed]

172. Rhett, J.M.; Yeh, E.S. The Potential for Connexin Hemichannels to Drive Breast Cancer Progression through Regulation of the Inflammatory Response. Int. J. Mol. Sci. 2018, 19, 1043. [CrossRef] [PubMed]

173. Soder, B.L.; Propst, J.T.; Brooks, T.M.; Goodwin, R.L.; Friedman, H.I.; Yost, M.J.; Gourdie, R.G. The connexin 43 carboxyl-terminal peptide ACT1 modulates the biological response to silicone implants. Plast Reconstr. Surg. 2009, 123, 1440-1451. [CrossRef] [PubMed]

174. Roskoski, R., Jr. Src protein-tyrosine kinase structure and regulation. Biochem. Biophys. Res. Commun. 2004, 324, 1155-1164. [CrossRef] [PubMed]

175. Kanemitsu, M.Y.; Loo, L.W.; Simon, S.; Lau, A.F.; Eckhart, W. Tyrosine phosphorylation of connexin 43 by v-Src is mediated by SH2 and SH3 domain interactions. J. Biol. Chem. 1997, 272, 22824-22831. [CrossRef]

176. Gangoso, E.; Thirant, C.; Chneiweiss, H.; Medina, J.M.; Tabernero, A. A cell-penetrating peptide based on the interaction between c-Src and connexin 43 reverses glioma stem cell phenotype. Cell Death Dis. 2014, 5, e1023. [CrossRef]

177. Han, X.; Zhang, W.; Yang, X.; Wheeler, C.G.; Langford, C.P.; Wu, L.; Filippova, N.; Friedman, G.K.; Ding, Q.; Fathallah-Shaykh, H.M.; et al. The role of Src family kinases in growth and migration of glioma stem cells. Int. J. Oncol. 2014, 45, 302-310. [CrossRef]

178. Singh, S.; Trevino, J.; Bora-Singhal, N.; Coppola, D.; Haura, E.; Altiok, S.; Chellappan, S.P. EGFR/Src/Akt signaling modulates Sox2 expression and self-renewal of stem-like side-population cells in non-small cell lung cancer. Mol. Cancer 2012, 11, 73. [CrossRef]

179. Gangoso, E.; Talaveron, R.; Jaraiz-Rodriguez, M.; Dominguez-Prieto, M.; Ezan, P.; Koulakoff, A.; Medina, J.M.; Giaume, C.; Tabernero, A. A c-Src Inhibitor Peptide Based on Connexin 43 Exerts Neuroprotective Effects through the Inhibition of Glial Hemichannel Activity. Front. Mol. Neurosci. 2017, 10, 418. [CrossRef]

180. He, D.; Li, H. Bifunctional Cx43 Mimic Peptide Grafted Hyaluronic Acid Hydrogels Inhibited Tumor Recurrence and Stimulated Wound Healing for Postsurgical Tumor Treatment. Adv. Funct. Mater. 2020, 30, 2004709. [CrossRef] 
181. Lamouille, S.; Smyth, J.W.; O’Rourke, L.; Kanabur, P.; Guo, S.; Jourdan, J.; Sheng, Z.; Gourdie, R.G. Abstract 4765: Targeting glioblastoma cancer stem cells with a novel Connexin 43 mimetic peptide. In Proceedings of the AACR Annual Meeting 2017, Washington, DC, USA, 1-5 April 2017. [CrossRef]

182. Sheng, Z. Connexin 43 peptidic medicine for glioblastoma stem cells. EBioMedicine 2021, 64, 103205. [CrossRef]

183. Grosely, R.; Kopanic, J.L.; Nabors, S.; Kieken, F.; Spagnol, G.; Al-Mugotir, M.; Zach, S.; Sorgen, P.L. Effects of phosphorylation on the structure and backbone dynamics of the intrinsically disordered connexin 43 C-terminal domain. J. Biol. Chem. 2013, 288, 24857-24870. [CrossRef]

184. Solan, J.L.; Lampe, P.D. Specific Cx43 phosphorylation events regulate gap junction turnover in vivo. FEBS Lett. 2014, 588, 1423-1429. [CrossRef] [PubMed]

185. Liao, C.K.; Cheng, H.H.; Wang, S.D.; Yeih, D.F.; Wang, S.M. PKC $\varepsilon$ mediates serine phosphorylation of connexin 43 induced by lysophosphatidylcholine in neonatal rat cardiomyocytes. Toxicology 2013, 314, 11-21. [CrossRef]

186. Solan, J.L.; Lampe, P.D. Kinase programs spatiotemporally regulate gap junction assembly and disassembly: Effects on wound repair. Semin Cell Dev. Biol. 2016, 50, 40-48. [CrossRef] [PubMed]

187. Acosta, M.L.; Mat Nor, M.N.; Guo, C.X.; Mugisho, O.O.; Coutinho, F.P.; Rupenthal, I.D.; Green, C.R. Connexin therapeutics: Blocking connexin hemichannel pores is distinct from blocking pannexin channels or gap junctions. Neural Regen. Res. 2021, 16, 482-488. [CrossRef] [PubMed]

188. Michalski, K.; Syrjanen, J.L.; Henze, E.; Kumpf, J.; Furukawa, H.; Kawate, T. The cryo-EM structure of a pannexin 1 reveals unique motifs for ion selection and inhibition. Elife 2020, 9, e54670. [CrossRef] [PubMed]

189. Qu, R.; Dong, L.; Zhang, J.; Yu, X.; Wang, L.; Zhu, S. Cryo-EM structure of human heptameric Pannexin 1 channel. Cell Res. 2020, 30, 446-448. [CrossRef] [PubMed]

190. Willebrords, J.; Maes, M.; Crespo Yanguas, S.; Vinken, M. Inhibitors of connexin and pannexin channels as potential therapeutics. Pharmacol. Ther. 2017, 180, 144-160. [CrossRef]

191. Billaud, M.; Lohman, A.W.; Straub, A.C.; Looft-Wilson, R.; Johnstone, S.R.; Araj, C.A.; Best, A.K.; Chekeni, F.B.; Ravichandran, K.S.; Penuela, S.; et al. Pannexin1 Regulates alpha 1-Adrenergic Receptor-Mediated Vasoconstriction. Circ. Res. 2011, 109, 80-85. [CrossRef]

192. Billaud, M.; Chiu, Y.H.; Lohman, A.W.; Parpaite, T.; Butcher, J.T.; Mutchler, S.M.; DeLalio, L.J.; Artamonov, M.V.; Sandilos, J.K.; Best, A.K.; et al. A molecular signature in the pannexin1 intracellular loop confers channel activation by the alpha1 adrenoreceptor in smooth muscle cells. Sci. Signal. 2015, 8, ra17. [CrossRef]

193. Weilinger, N.L.; Tang, P.L.; Thompson, R.J. Anoxia-induced NMDA receptor activation opens pannexin channels via Src family kinases. J. Neurosci. 2012, 32, 12579-12588. [CrossRef]

194. Weilinger, N.L.; Lohman, A.W.; Rakai, B.D.; Ma, E.M.; Bialecki, J.; Maslieieva, V.; Rilea, T.; Bandet, M.V.; Ikuta, N.T.; Scott, L.; et al. Metabotropic NMDA receptor signaling couples Src family kinases to pannexin-1 during excitotoxicity. Nat. Neurosci. 2016, 19, 432-442. [CrossRef] [PubMed]

195. Diezmos, E.F.; Markus, I.; Perera, D.S.; Gan, S.; Zhang, L.; Sandow, S.L.; Bertrand, P.P.; Liu, L. Blockade of Pannexin-1 Channels and Purinergic P2X7 Receptors Shows Protective Effects Against Cytokines-Induced Colitis of Human Colonic Mucosa. Front. Pharmacol. 2018, 9, 865. [CrossRef]

196. Shoji, K.F.; Sáez, P.J.; Harcha, P.A.; Aguila, H.L.; Sáez, J.C. Pannexin1 channels act downstream of P2X 7 receptors in ATP-induced murine T-cell death. Channels 2014, 8, 142-156. [CrossRef]

197. Garré, J.M.; Yang, G.; Bukauskas, F.F.; Bennett, M.V. FGF-1 Triggers Pannexin-1 Hemichannel Opening in Spinal Astrocytes of Rodents and Promotes Inflammatory Responses in Acute Spinal Cord Slices. J. Neurosci. 2016, 36, 4785-4801. [CrossRef] [PubMed]

198. Huang, G.Y.; Xie, L.J.; Linask, K.L.; Zhang, C.; Zhao, X.Q.; Yang, Y.; Zhou, G.M.; Wu, Y.J.; Marquez-Rosado, L.; McElhinney, D.B.; et al. Evaluating the role of connexin 43 in congenital heart disease: Screening for mutations in patients with outflow tract anomalies and the analysis of knock-in mouse models. J. Cardiovasc Dis. Res. 2011, 2, 206-212. [CrossRef]

199. Salameh, A.; Blanke, K.; Daehnert, I. Role of connexins in human congenital heart disease: The chicken and egg problem. Front. Pharmacol. 2013, 4, 70. [CrossRef]

200. Delmar, M.; Makita, N. Cardiac connexins, mutations and arrhythmias. Curr Opin Cardiol. 2012, 27, 236-241. [CrossRef] [PubMed]

201. Boengler, K.; Schulz, R. Connexin 43 and Mitochondria in Cardiovascular Health and Disease. Adv. Exp. Med. Biol. 2017, 982, 227-246. [CrossRef]

202. Srinivas, M.; Verselis, V.K.; White, T.W. Human diseases associated with connexin mutations. Biochim. Biophys. Acta Biomembr. 2018, 1860, 192-201. [CrossRef] [PubMed]

203. Fetoni, A.R.; Zorzi, V.; Paciello, F.; Ziraldo, G.; Peres, C.; Raspa, M.; Scavizzi, F.; Salvatore, A.M.; Crispino, G.; Tognola, G.; et al. Cx26 partial loss causes accelerated presbycusis by redox imbalance and dysregulation of Nfr2 pathway. Redox Biol. 2018, 19, 301-317. [CrossRef] [PubMed]

204. Beach, R.; Abitbol, J.M.; Allman, B.L.; Esseltine, J.L.; Shao, Q.; Laird, D.W. GJB2 Mutations Linked to Hearing Loss Exhibit Differential Trafficking and Functional Defects as Revealed in Cochlear-Relevant Cells. Front. Cell Dev. Biol. $2020,8,215$. [CrossRef] [PubMed] 
205. Shuja, Z.; Li, L.; Gupta, S.; Mese, G.; White, T.W. Connexin 26 Mutations Causing Palmoplantar Keratoderma and Deafness Interact with Connexin 43, Modifying Gap Junction and Hemichannel Properties. J. Invest. Dermatol. 2016, 136, $225-235$. [CrossRef]

206. Maestrini, E.; Korge, B.P.; Ocana-Sierra, J.; Calzolari, E.; Cambiaghi, S.; Scudder, P.M.; Hovnanian, A.; Monaco, A.P.; Munro, C.S A missense mutation in connexin 26, D66H, causes mutilating keratoderma with sensorineural deafness (Vohwinkel's syndrome) in three unrelated families. Hum. Mol. Genet. 1999, 8, 1237-1243. [CrossRef]

207. Yang, S.H.; Clemett, C.A.; Brimble, M.A.; O'Carroll, S.J.; Harris, P.W.R. Synthesis and biological evaluation of S-lipidated lipopeptides of a connexin 43 channel inhibitory peptide. RSC Med. Chem. 2020, 11, 1041-1047. [CrossRef]

208. Marsh, S.R.; Pridham, K.J.; Jourdan, J.; Gourdie, R.G. Novel Protocols for Scalable Production of High Quality Purified Small Extracellular Vesicles from Bovine Milk. Nanotheranostics 2021, 5, 488-498. [CrossRef] 